\title{
CONSIDERACIONES EN TORNO A LOS MOSAICOS ROMANOS DE CHIPRE
}

\author{
JOSÉ MARÍA BLÁZQUEZ MARTÍNEZ \\ GUADALUPE LÓPEZ MONTEAGUDO \\ M. LUZ NEIRA JIMÉNEZ \\ Universidad Complutense / CSIC
}

\begin{abstract}
Se pasa revista a un amplio conjunto de los mosaicos de Chipre, que cubren la práctica totalidad de los repertorios iconográficos y decorativos característicos: mitológicos, geométricos, etc.

We have reviewed a large set of the mosaics from Cyprus, contained in nearly all the typical collections of icons and decorative arts: mythological, geometrical, etc.
\end{abstract}

\section{MOSAICOS ROMANOS DE PAPHOS}

La isla de Chipre fue en la Antigüedad una región de gran importancia cultural, religiosa y económica. Su excelente situación geográfica, en las proximidades de la costa sur de Anatolia, de la costa occidental de Siria y de Fenicia, así como su relativa proximidad a Egipto, hicieron de ella punto de encuentro de culturas y de intereses comerciales. En el segundo milenio fue colonizada por los griegos micénicos, es decir, los llamados aqueos por Homero, y en el siglo IX, o aún antes, por los fenicios. Chipre constituía un foco de atracción por sus minas, cuando el próximo Oriente o no las tenía o eran muy escasas y poco importantes, y también por sus bosques, de donde se obtenía la madera necesaria para la construcción naval y las pesquerías.
El geógrafo griego Estrabón, contemporáneo del emperador Augusto, y Pausanias, que vivió a finales de los Antoninos y escribió una guía de Grecia recogiendo multitud de datos históricos, geográficos, artísticos, religiosos, económicos, etc., nos han transmitido la noticia de que Paphos, la antigua Paleopaphos, fue fundada por Agapenor, rey de Tegea en Grecia, al finalizar la guerra de Troya, esto es, en torno al 1250 a.C. Esta Paphos antigua fue una ciudad próspera durante muchos siglos. Era famosa por su santuario consagrado a Afrodita, equivalente a la Astarté fenicia, diosa de la fecundidad, que a su vez era la Isthar babilonia, la Inanna de los sumerios o la Tanit de los cartagineses. Tenía Paphos un buen puerto de mar que mantenía la ciudad abierta a todo tipo de relaciones y de influencias. La extensión del núcleo habitado era de $950.000 \mathrm{~m}^{2}$, habiendo puesto al descubierto las excava- 
ciones modernas parte del plano del sector sudoeste, donde se encuentra la Villa de Teseo. La ciudad tuvo desde el principio planta ortogonal, formando insulae o bloques de viviendas. En Paphos se diferencian dos zonas: la comercial, situada en las proximidades del Odeón, y la residencial que se extendía al oeste del puerto.

Paleopaphos contó en el siglo IV a.C. con un excelente rey, de nombre Nicocles, que junto a Evagoras, rey también de Chipre, fueron los prototipos ideales de la monarquía propuesta por Platón y Aristóteles como forma política de gobierno. En el siglo IV a.C. se fundó Paphos y la isla pasó a poder de los Ptolomeos, que la convirtieron por su proximidad a Alejandría en el principal puerto fuera de Egipto. En el siglo II a.C. Paphos era la capital de la isla y residencia del general ptolemaico. En el año 54 a.C., bajo el dominio de los romanos, Paphos continuó siendo la capital política y administrativa de Chipre y lugar de residencia del procónsul. Los años de su mayor prosperidad coinciden con los gobiernos de los emperadores antoninos y severos, como han puesto de manifiesto las excavaciones modernas. Paphos contaba con excelentes edificios civiles y militares, entre los que son dignos de mencionar el agora, el teatro, el odeón, el anfiteatro y los templos dedicados a Asklepios, dios de la medicina, a Zeus, Leto, Apolo, Artemis, Afrodita y a Dionysos. El cristianismo fue introducido pronto en la isla por Pablo y Bernabé.

La ciudad de Paphos fue seriamente dañada por varios terremotos durante el siglo IV. Después de ser reconstruida, recibió el nombre de Constantia, contando aún a finales del siglo IV con excelentes construcciones, como la primera basílica cristiana. La decadencia de Nea Paphos coincide con la llegada de los árabes.

Las excavaciones modernas realizadas en la ciudad de época romana han sacado a la luz varias casas decoradas con excelentes mosaicos: las Casas de Dionysos, de Orfeo, de Teseo y de Aión.

\section{Casa de Dionysos}

Es la mansión que ha proporcionado uno de los conjuntos de mosaicos más espectaculares no sólo de la isla, sino de todo el Imperio Romano, por su número, calidad artística y originalidad. Su excavación data de los años 1962-1965 y al principio se pensó que podía tratarse de la residencia de un alto oficial romano o del mismo procónsul, pero esta sospecha desapareció cuando se descubrió la villa de Teseo, verdadera residencia oficial. En el siglo II lo frecuente era que las casas de Paphos estuvieran adornadas con ricos mosaicos y la Casa de Dionysos no constituía una excepción.

La casa tiene una extensión de $2.000 \mathrm{~m}^{2}$, de los que 556 $\mathrm{m}^{2}$ están cubiertos de mosaicos. De planta rectangular y rodeada de calles por los cuatro lados, seguía el modelo de las casas del período griego y romano, con atrio en el centro y corredor, alrededor del cual se disponían las habitaciones, decoradas con mosaicos, cuya función no se ha podido determinar con seguridad. Las estancias privadas se encontraban en el ángulo noroeste. La casa contaba con otros dos atrios.

\section{Mosaicos}

Salvo el mosaico con Escila, todos los pavimentos se conservan in situ, habiéndose construido sobre ellos una gran edificación cubierta y provista de pasarelas elevadas de maderas, que permiten la cómoda contemplación de los mosaicos y constituyen un modelo a seguir en este tipo de casas adornadas con ricos pavimentos. Los mosaicos se caracterizan por el uso de tesselas de vivos colores, procedentes de canteras locales, siendo de vidrio las de color verde, amarillo y azul. Los excavadores de la villa que han estudiado los mosaicos, D. Michaelides y W.A. Daszewski (este último tuvo la amabilidad, durante nuestra visita, de mostrarnos y explicarnos toda la excavación y los mosaicos), son de la opinión de que los musivarios, que eran esclavos o libertos, usaban unos «copy books» o cartones de donde copiaban los grupos o las figuras, introduciendo modificaciones o adaptaciones. R.J.A. Wilson, al estudiar recientemente las relaciones de un grupo numeroso de mosaicos sicilianos del Bajo Imperio, en conexión con los africanos de esta misma época, se pregunta si se utilizaban «copy books», o llegaban artesanos de Africa o Sicilia, o se transportaban los mosaicos ya confeccionados. A. Balil y D. Fernández Galiano dudan de la existencia de africanismo en los mosaicos hispanos y piensan más bien que los temas se ponían de moda y de ahí que se les encuentre en todo el Imperio. No puede negarse, sin embargo, la evidencia de los paralelos existentes entre los mosaicos africanos, sicilianos e hispanos; por ejemplo, los peces del pavimento de Villavidel (León) se encuentran exactamente iguales en mosaicos de Cerdeña; el mosaico de la Gran Caza de Pedrosa de la Vega (Palencia) está íntimamente relacionado con las escenas del pavimento siciliano de Tellaro y no con los sirios, como el mosaico de la caza de Antioquía. Nosotros, del estudio minucioso de este último, hemos llegado a la conclusión de que hay detalles muy concretos que llevan al norte de Africa y pensamos que se utilizaban «copy books» que se interpretaban libremente y no de manera servil. Se observa cómo se combinaban grupos y cómo estos se disponían sin pretender formar una gran unidad de composición. También está claro que en un mismo pavimento trabajaban varios mosaistas de diferente calidad artística. Del hecho de que de los once nombres de musivarios documentados en mosaicos hispanos, tan sólo uno pueda ser de procedencia africana, se deduce que los artesanos que confeccionaron los pavimentos hispanos no procedían del Africa Proconsular. La 


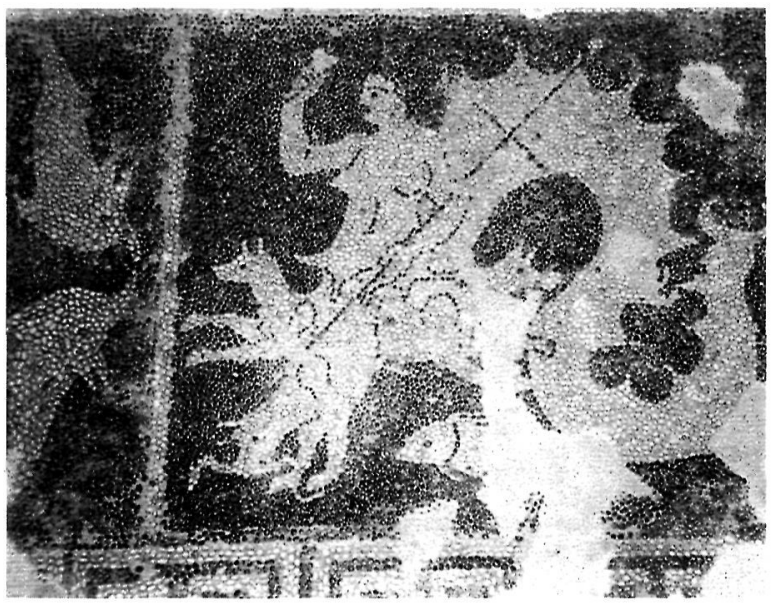

Fig. 1.- Paphos. Casa de Dionysos. Mosaico con Escila.

inscripción de un mosaico de la villa toledana de Carranque, fechado en el Bajo Imperio, indica que el dibujo se debe a un artista y la confección del mosaico a otro.

En Chipre debía haber zonas, talleres o escuelas de mosaicos, W.A. Daszewski y D. Michaelides creen que los musivarios no tenían un conocimiento correcto de los temas ni de los personajes que interpretaban y a ello se debe la introducción de novedades en cuanto a la edad, por ejemplo, y la combinación de escenas de diferente origen o tiempo, o más concretamente de dos ciclos, para lograr una composición. Este es el caso del mosaico de Beja, de finales del siglo $\mathrm{V}$ o comienzos del siguiente, según K.M.D. Dunbabin como ya sugirió Yacoub. También A.M. Canto, al publicar el mosaico italicense del nacimiento de Venus, observó que modelos helenísticos con letreros en griego se combinaban con otros de procedencia africana con inscripciones en latín. Al parecer, el musivario más importante realizaba las figuras principales, mientras que a artesanos de inferior calidad les eran encomendadas las escenas secundarias o los temas geométricos.

\section{Mosaico con Escila (fig. 1).}

Uno de los mosaicos más interesantes de todo este conjunto está decorado con el monstruo marino Escila, parte mujer, parte pez y parte perro, realizado con guijarros blancos y negros. Esta técnica, de origen oriental (Arlan, Tash, Gordion, Tell Basir, Tirinto, etc.), fue introducida en Occidente por los fenicios en el siglo VIII a.C., estando documentada en el santuario de Cástulo (Jaén) en los siglos VIIIVI a.C. Se generaliza en los siglos IV y comienzos del III a.C., conociéndose en Chipre solamente otro pavimento similar pero de fecha más reciente. Con esta técnica de guijarros se confeccionaron algunas de las obras cumbres de la musivaria

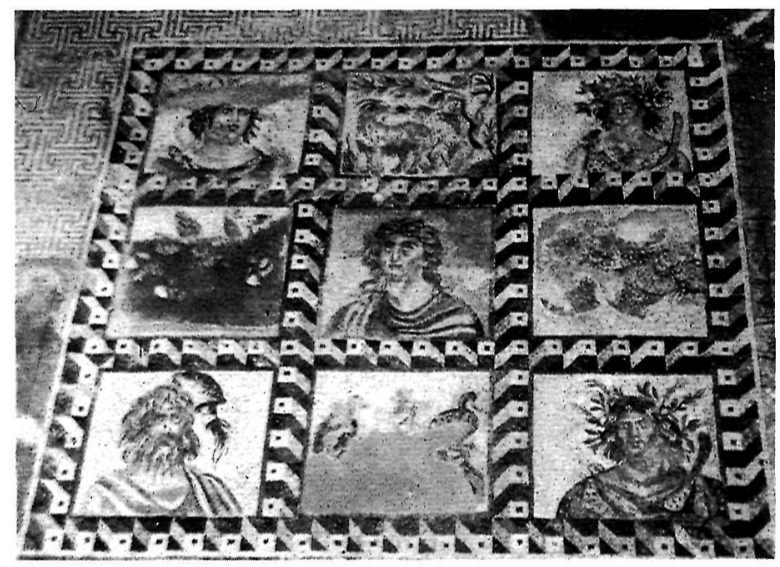

Fig.2.- Paphos. Casa de Dionysos. Mosaico con las cuatro Estaciones.

helenística, como los famosos mosaicos de Pella, la capital de Macedonia, con la caza del león, del ciervo y con Dionysos sobre pantera, fechados entre los años 330-300 a.C., de fuertes raíces hundidas en la tradición clásica.

\section{Mosaico con las cuatro estaciones (fig. 2)}

El panel de la habitación 3 representaba los bustos de las cuatro estaciones, dentro de cuadros, con sus correspondientes atributos; Dionysos y Aión en el centro; y escenas campestres entre las imágenes de las estaciones. Los cuadros están enmarcados por filas de cubos, frecuentes en la arquitectura. Los rostros de las estaciones se caracterizan por un estudio anatómico perfecto y por la gran variedad de tonalidades magníficamente lograda, al igual que los cabellos o la piel de la cabra. Son rostros muy expresivos.

El esquema cuadrangular del campo musivo con una figura central es conocido en el África Proconsular, mosaico de Thysdrus con Venus y las estaciones, datado en los años 280300. En Hispania se conocen dos pavimentos con las cuatro estaciones dentro de cuadrados, sin figura en el centro, descubiertos en las villas romanas de Complutum y de Comunión (Álava), ambos del Bajo Imperio. Un mosaico de Dionysos rodeado de los medallones con las estaciones se ha encontrado en Lambaesis, con una fecha de comienzos del siglo III.

\section{Pompa triumphalis dionisiaca (figs. 3-5)}

El tema es bien conocido en el Africa Proconsular, en donde ha sido estudiado por L. Foucher, y en Hispania por D. Fernández Galiano y J.M. Blázquez. En Africa esta composición hace su aparición a partir del año 200 en Hadrumetum, Casa del Arsenal, datado en 200-210, mientras que en 


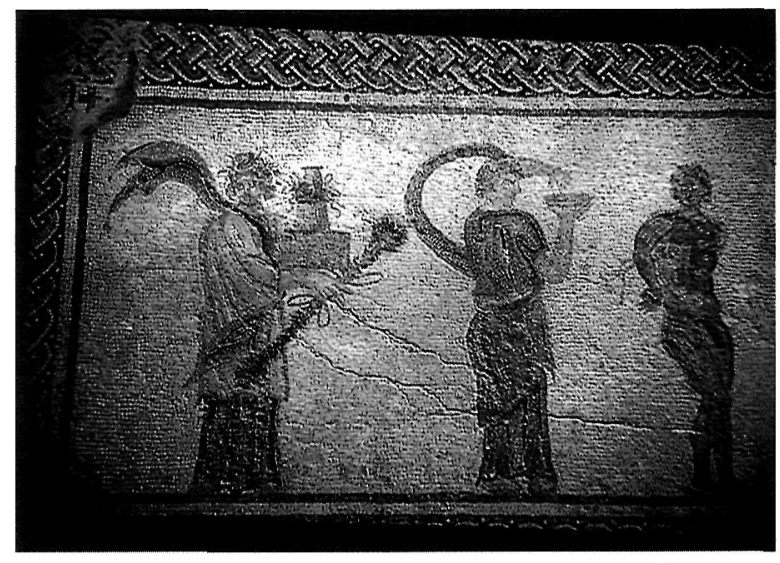

Fig. 3.- Paphos. Casa de Dionysos. Mosaico de la Pompa Triumphalis Dionisisca. Detalle del lado izquierdo.

Hispania se documenta unos cincuenta años antes en el mosaico de Zaragoza, actualmente en el MAN de Madrid.

En el pavimento de Paphos, Dionysos, sosteniendo un largo thyrsos, es transportado en un carro tirado por tigresas. Le sigue un sátiro que lleva una crátera y un pellejo de vino. Detrás del carro Pan, que levanta el pedum y sostiene en su mano izquierda un pequeño escudo; un esclavo indio con las manos atadas a la espalda; y dos bacantes, la primera hace una libación en un cuenco, mientras su compañera, con corona de flores y thyrsos, transporta la mística cista dionisiaca. Sileno guía a las panteras con un thyrsos. Delante del cortejo se encuentra un indio rodilla en tierra, una bacante tocando los címbalos y un hombre desnudo, con párdalis colgando del

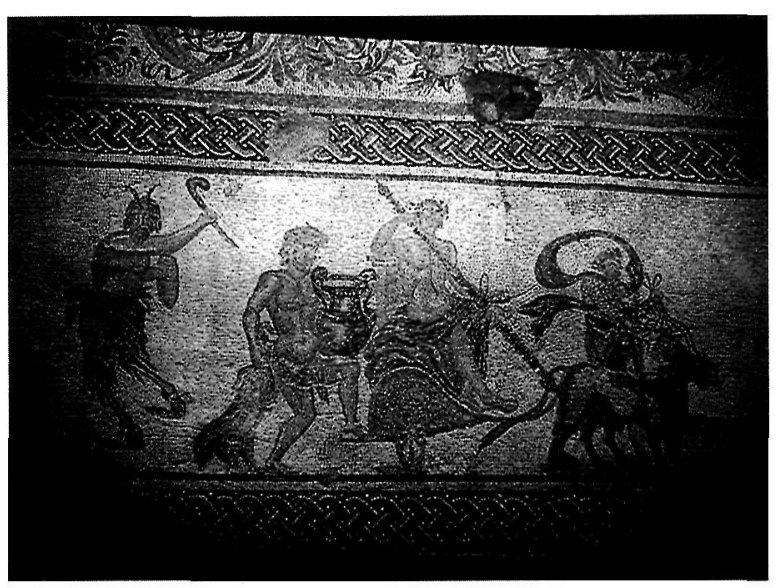

Fig. 4.- Paphos. Casa de Dionysos. Mosaico de la Pompa Triumphalis dionisiaca. Parte central

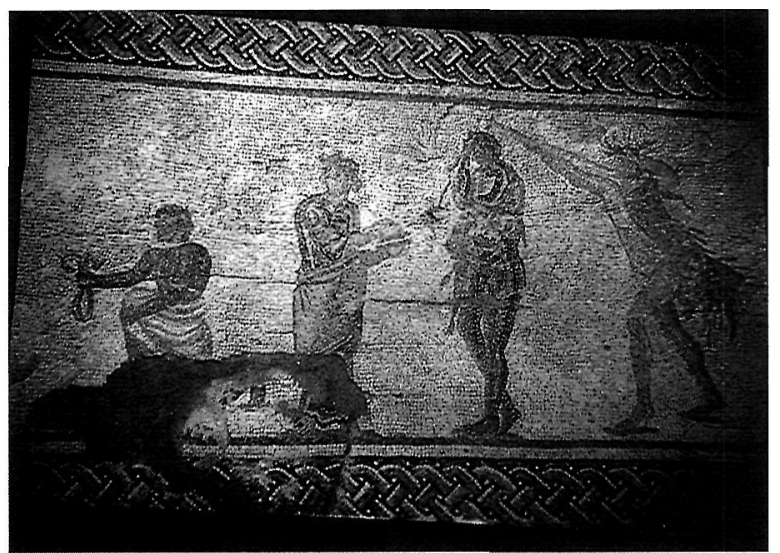

Fig. 5.- Paphos. Casa de Dionysos. Mosaico de la Pompa Triumphalis dionisiaca. Detalle del lado derecho

hombro izquierdo, que toca una larga trompeta; entre ellos danza un indio. No hay duda de que el mosaico representa la vuelta triunfante de Dionysos de la India, tratada de una manera totalmente original que no tiene paralelos, ni en la colocación de las figuras ni en sus actitudes, en los relieves de los sarcófagos con este mismo tema, como son las piezas de Camino Rospighosi, del 200; Museo Capitolino, 190-200; Palazzo Giustiniani, en torno al 210, todos en Roma; ni en los mosaicos de Antioquía: Casa del Triunfo de Dionysos, con las figuras de frente; ni en los de Palestina, Cheikh Zouede, del siglo III; de Africa, Hadrumetum, Thysdrus, Casa de Sileno, datado en 260-280; o de Hispania, Zaragoza, Torre de Palma (Portugal), de época constantiniana.

\section{Fedra e Hipólito (fig. 6)}

Los temas mitológicos decoraban muchos mosaicos de Paphos. En la Casa de Dionysos se representan las leyendas de Fedra e Hipólito, de Ganímedes, Piramos y Thisbe, Icaros y Dionysos, Neptuno y Amymone, Apolo y Dafne. Todos los pavimentos son de una gran calidad artística, con excelente estudio de la anatomía humana, del sombreado de las carnes y del colorido y de los pliegues del vestido, así como con un dominio absoluto del movimiento.

El mosaico de Fedra e Hipólito es uno de los mejores de esta casa. Representa el momento en que Hipólito ha leído la declaración de amor de Fedra. El mosaísta retrata de forma magnífica la indecisión en el rostro y actitud de Hipólito, que llega de caza acompañado de su perro. Junto a él se encuentra sentada Fedra, ansiosa, como lo expresa muy bien la actitud de los ojos levantados hacia arriba y las manos caídas lánguidamente esperando la respuesta. A su lado, un eros con arco y antorcha completa la escena. 


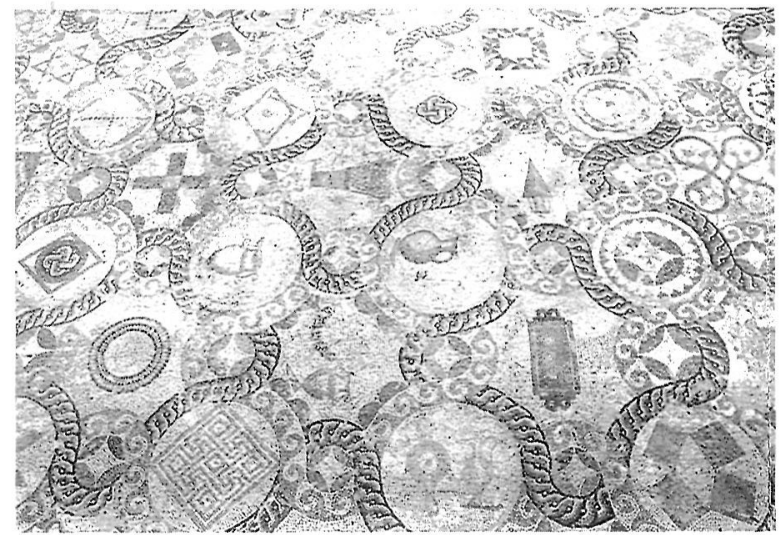

Fig. 6.- Paphos. Cssa de Dionysos. Fedra e Hipólito.

\section{Mosaico geométrico (fig. 7)}

Este pavimento de hall sobresale por su polícroma decoración geométrica, lograda a base de una sucesión de círculos, con jarros de diferentes formas y otros utensilios de uso doméstico, crátera, ánfora, jarro, espejo, etc.

\section{Rapto de Ganimedes (fig. 8)}

Es también uno de los mosaicos más bellos de la casa. Representa el momento en el que el águila, de cabeza y alas majestuosas, lleva por el aire al copero de Zeus hacia el Olimpo. Ganimedes, totalmente desnudo, se sujeta transversalmente al cuello del águila.

\section{Mosaico geométrico con paneles (fig. 9)}

Aunque las escenas mitológicas son las más frecuentes,

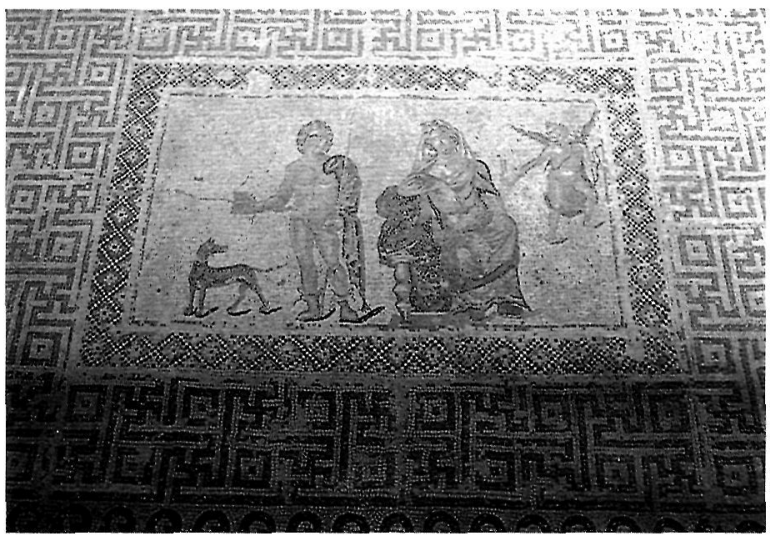

Fig. 7.- Paphos. Casa de Dionysos. Mosaico geométrico.

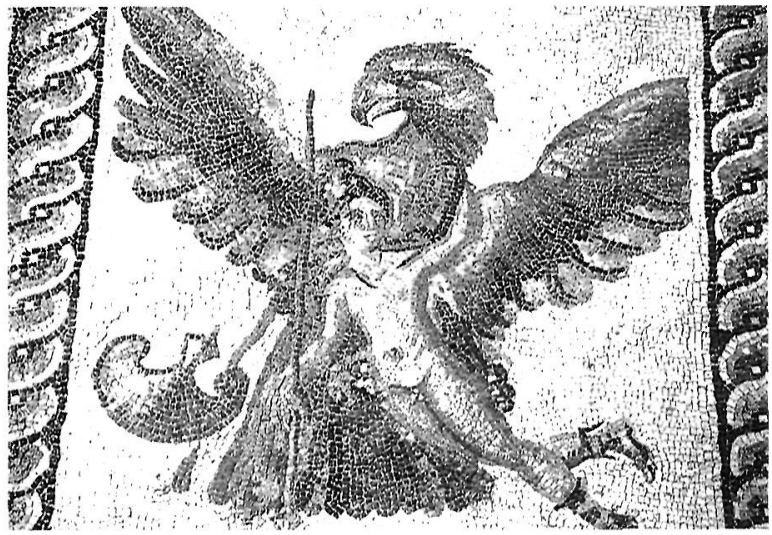

Fig. 8.- Paphos. Casa de Dionysos. Rapto de Ganimedes.

no faltan los temas geométricos, como este pavimento decorado con paneles de diferentes figuras geométricas. El efecto del colorido es sorprendente, al igual que los juegos de luces de las figuras. Este sistema de decoración es bien conocido en mosaicos de Gallia y raro en pavimentos de las provincias orientales del Imperio Romano, y de ahí el valor de este mosaico de la Casa de Dionysos.

Piramos y Thisbe (fig. 10)

Esta leyenda, inmortalizada por Ovidio en el libro cuarto de sus Metamorfosis, decora un mosaico de esta excepcional casa de Nea Paphos. Narra la desgraciada historia de dos jóvenes de Babilonia que se amaban en secreto por proceder de familias enemigas. Un día deciden tener un encuentro nocturno. La primera en llegar a la fuente es Thisbe que, al encontrarse con una leona, huye perdiendo el velo en la huida. Cuando Piramos llega al lugar y contempla el velo ensangren-

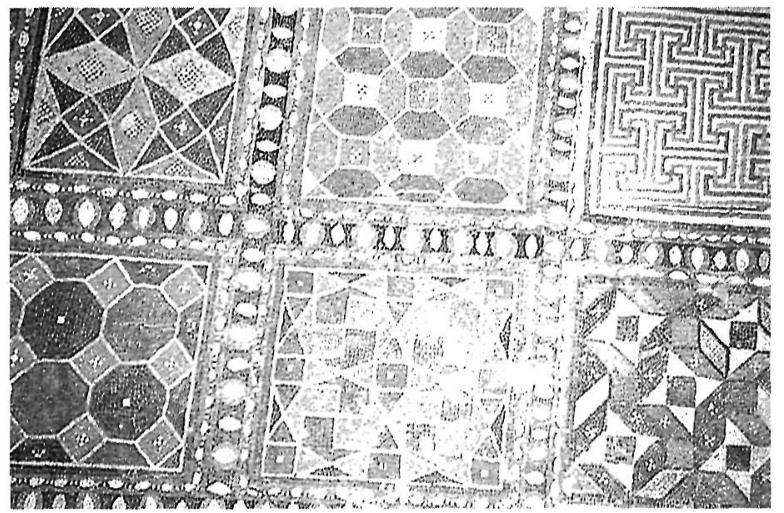

Fig.9.- Paphos. Casa de Dionysos. Mosaico geométrico con paneles. 


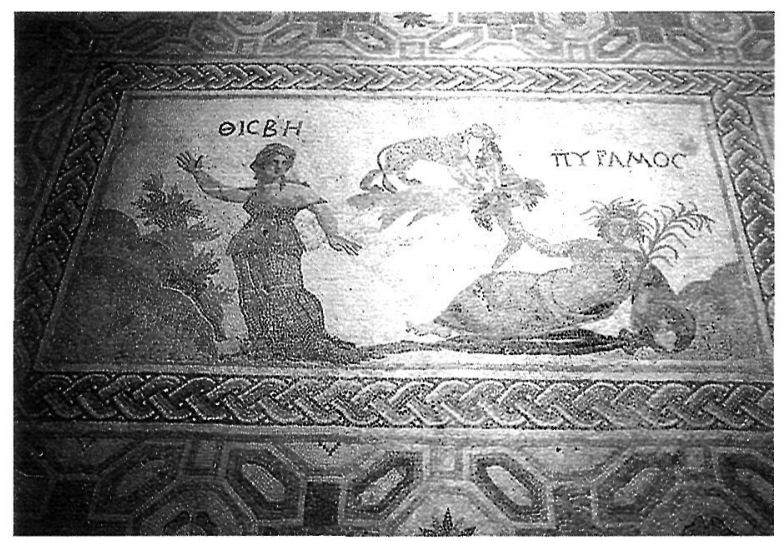

Fig. 10.- Paphos. Casa de Dionysos. Piramos y Tisbe.

tado por la leona, cree que su amada ha sido devorada por la fiera y se suicida. Vuelta Thisbe a la fuente, ante la visión del cuerpo de su amado atravesado por una espada, se da muerte con la misma arma. El mosaico representa el momento en que un leopardo desgarra el velo y a Thisbe aterrada, como lo indican el gesto de los ojos y del rostro y la postura de las manos, al contemplar no el cuerpo de su amado, sino la imagen de un dios río, representado a la manera tradicional de los ríos en el arte clásico, llamado también Piramos y mencionado por Estrabón en Sicilia. La misma interpretación se encuentra en el mosaico italicense de los Amores de Zeus. Lo más sorprendente de esta excepcional pieza es la forma cómo el musivario ha logrado plasmar el estado de ánimo de la doncella. El tema se repite en un mosaico de Carranque (Toledo). Dos bustos del dios río Piramos están representados en el mosaico de la Casa de los Pórticos y del Fenix en Antioquía.

Icaros y Dionysos (figs. 11-12)

Este tema ocupa un largo panel del pórtico, junto a la escena anterior. Icaros era un jardinero de Atenas que ofreció hospitalidad a Dionysos en su visita a la ciudad. En agradecimiento, el dios le enseñó a cultivar la vid y a obtener vino de su fruto. El mosaista ha escogido el momento de la leyenda en el que Icaros vuelve con el carro de bueyes repleto de odres de vino. A su izquierda se representan los dos pastores borrachos que matan a Icaros después que éste les ofreciera vino, contra las indicaciones de Dionysos. En el lado opuesto Dionysos, sentado en una roca, ofrece un racimo de uvas a la ninfa Acme, la cual aparece semidesnuda sentada en el suelo. La expresión de ambos protagonistas está bien lograda e indica los sentimientos del alma en ese momento. Como es frecuente en estos mosaicos, cada personaje va acompañado de un letrero que lo identifica. El uso de letreros, tan fre-

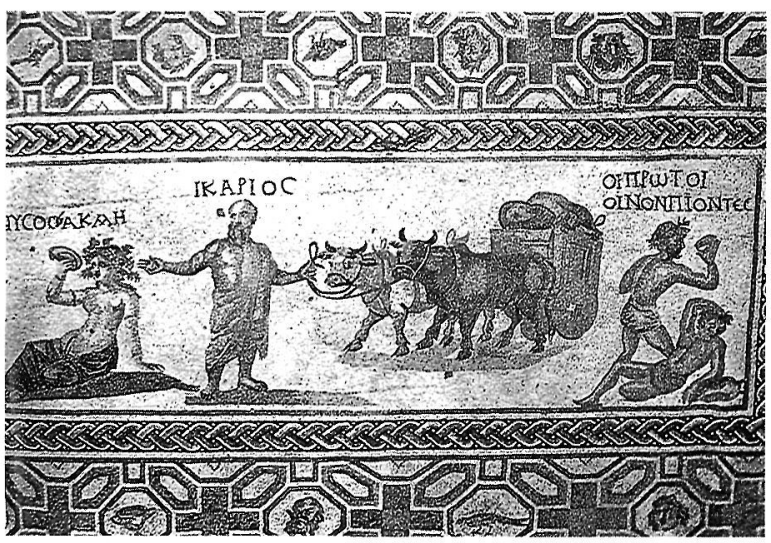

Fig. 11.- Paphos. Casa de Dionysos. Mosaico de Icaros y Dionysos. Detalle del lado izquierdo.

cuente en mosaicos africanos, es una costumbre seguida también por los musivarios de esta casa de Nea Paphos. Una excepción a la regla son los dos mosaicos siguientes que forman parte también de este panel.

\section{Neptuno y Amymone (fig. 13)}

El mosaista ha elegido de la leyenda de Neptuno y Amymone el momento en que el dios, después de rechazar a un sátiro que quería poseer a la ninfa, se dirige hacia la joven con el tridente al hombro. Amymone, que aparece sentada en una roca, concede a Neptuno lo que le había negado al sátiro. Entre ambos personajes marcha Cupido llevando una especie de parasol y una antorcha. El artesano ha sabido captar de forma maravillosa la actitud de entrega amorosa de la ninfa al dios de las aguas. Es de destacar el estudio anatómico de Neptuno, con

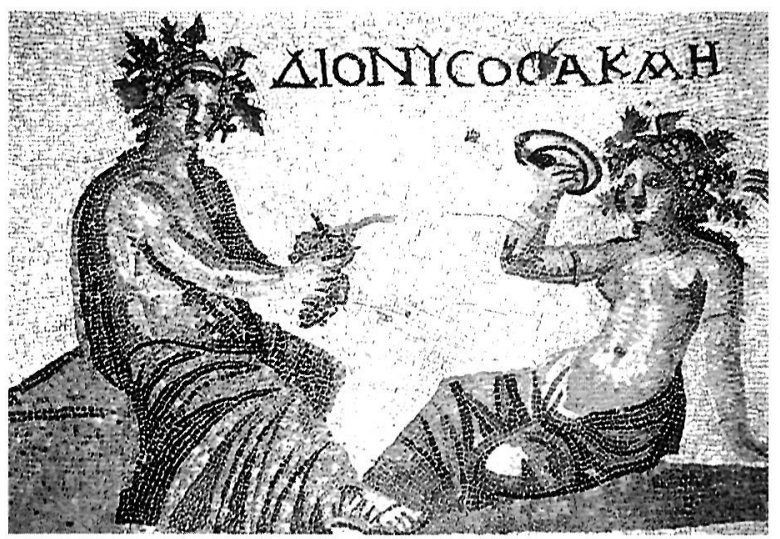

Fig. 12.- Paphos. Casa de Dionysos. Mosaico de Icaros y Dionysos. Detalle del lado derecho con Dionysos y Acmé. 


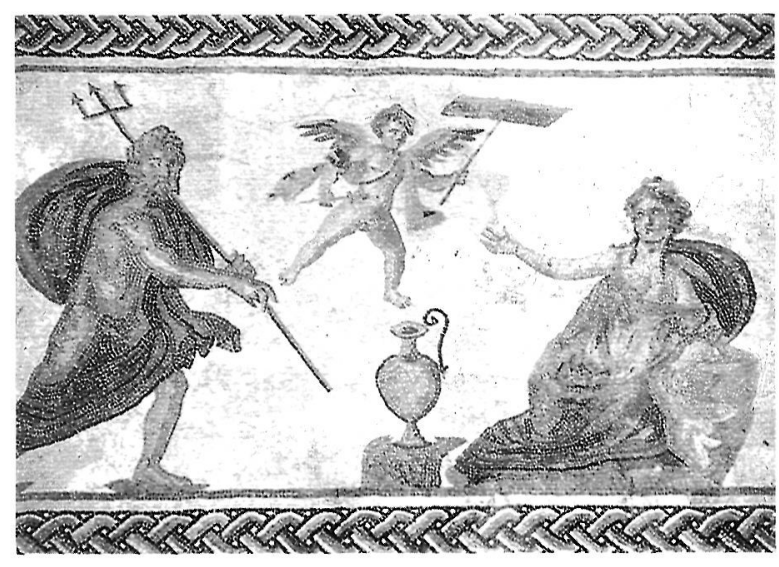

Fig. 13.- Paphos. Casa de Dionysos. Neptuno y Amymone.

un sombreado muy logrado, así como el tratamiento de los pliegues de los vestidos en ambos personajes. El tema se repite de nuevo en Carranque, aunque tratado de forma diferente.

\section{Apolo y Dafne (fig. 14)}

Este mito, uno de los más conocidos de la Antigüedad, ha sido bien descrito en el libro primero de las Metamorfosis de Ovidio. Dafne es perseguida por Apolo al enamorarse de ella. La ninfa suplica a su padre, el dios río Peleo, que la transforme en árbol para librarse del acoso del dios. El artesano de este mosaico de Nea Paphos ha representado el momento en el que Dafne, junto a su padre, que aparece como río según la imagen tradicional, empieza a convertirse en laurel, y a Apolo que con gesto amoroso se dirige hacia ella. La leyenda de Apolo y Dafne se representa igualmente en un mosaico de la

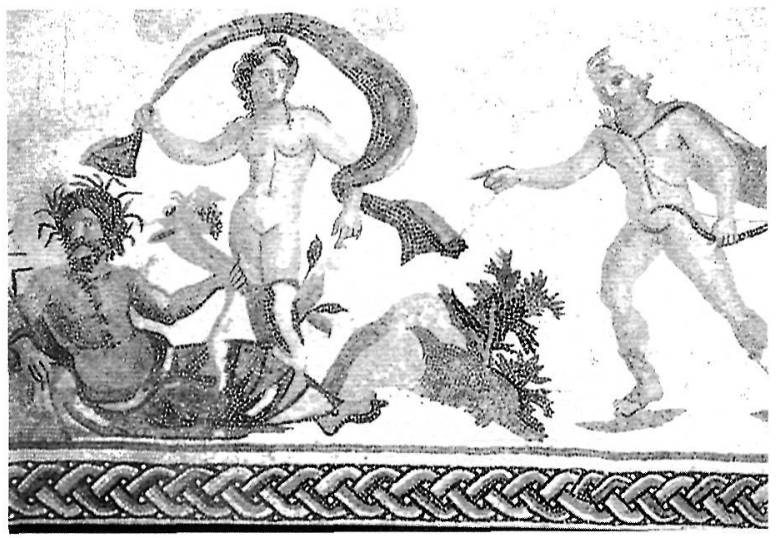

Fig. 14.- Paphos. Casa de Dionysos. Apolo y Daphne.

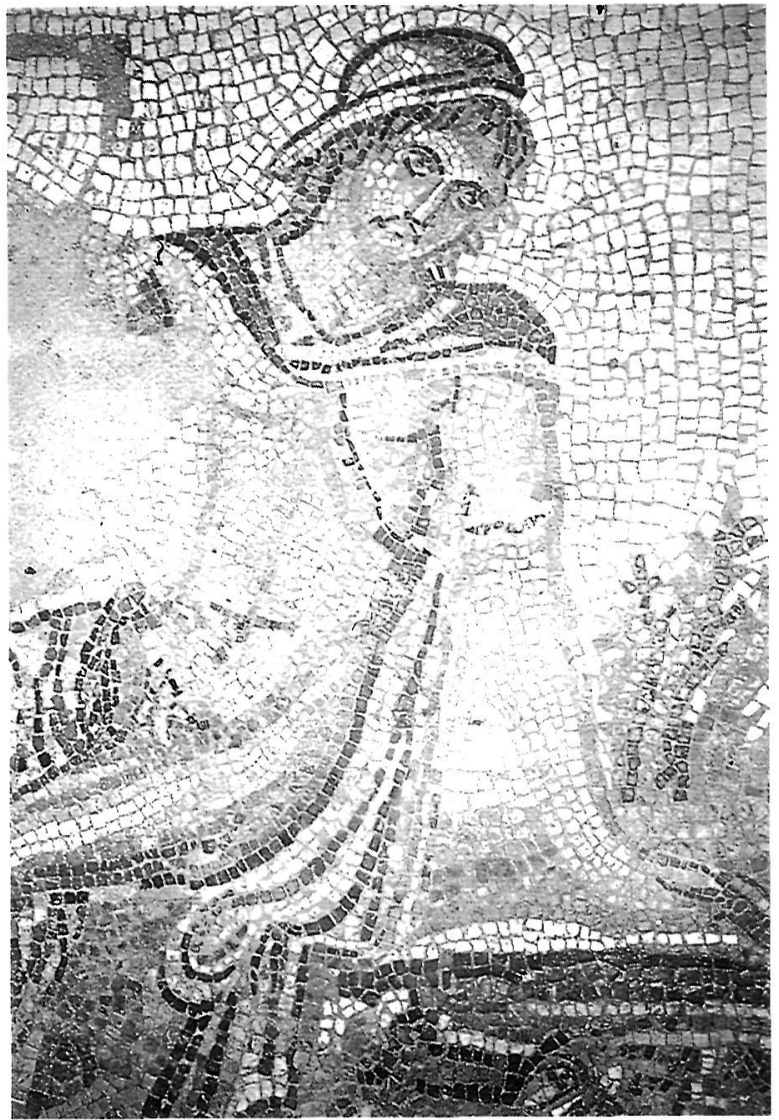

Fig. 15.- Paphos. Casa de Dionysos.Narciso.

villa lusitana de Torre de Palma, aunque el estilo y la actitud de los personajes son diferentes. En Hispania, Apolo aparece sentado con la cabeza apoyada sobre la lira, mientras que Dafne está vista de frente, en el momento de convertirse en laurel, con el velo arqueado por detrás de la espalda. Peleo está ausente en el mosaico lusitano. Es interesante la comparación de estos dos mosaicos para conocer los distintos modelos existentes sobre un mismo tema.

La Casa de Dionysos todavía ofrece otros mosaicos de buen arte, como uno con la figura pensativa de Narciso, contemplando su rostro en el agua (fig. 15). También se representa una escena campestre, tan del gusto de los mosaistas africanos (fig. 16). Baste recordar el grupo de mosaicos con escenas rurales de la Casa de los Laberii en Oudna, fechado entre los años 160-180; las labores del campo de Cherchel, la antigua Cesarea, de la segunda mitad del siglo IV; y ya en Sicilia los erotes vendimiadores de Piazza Armerina, fechado por K.M.D. Dunbabin en 310-330. En este conjunto no podía faltar la presencia de un pavo real, con la cola explayada, en 


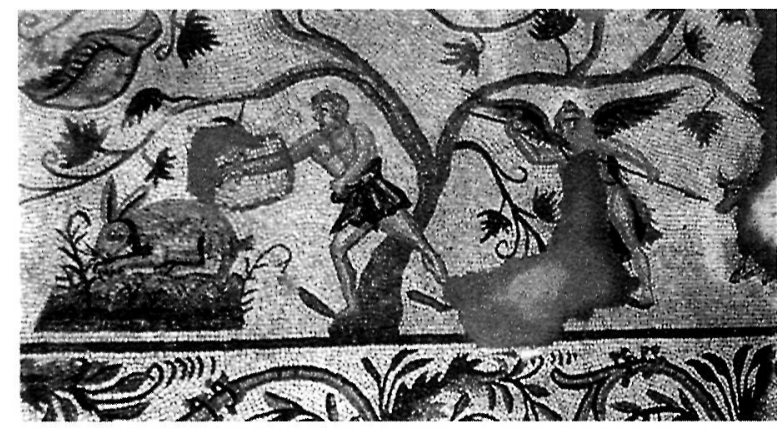

Fig. 16.- Paphos. Casa de Dionysos. Escena campestre.

compañía de Eros (fig. 17). El pavo real, con la cola abierta en abanico (fig. 18), se repite en mosaicos africanos: Bir-Chana, de finales del siglo II; Cartago, Casa del pavo real, de la mitad del siglo IV; y también de Hispania, villa de Portman, de finales del siglo IV, aquí en compañía de Venus. Otros pavimentos representan diversas escenas de caza (fig. 19).

\section{Casa de Orfeo}

Situada al Oeste de la villa de Teseo, esta casa recibe su nombre del mosaico de Orfeo entre las fieras, que cubría una gran sala (fig. 20). El tema gozó de una gran aceptación entre los musivarios, documentándose cuatro piezas en Hispania, mientras que sólo en Britania Smith ha podido catalogar once. El mosaico de Nea Paphos es de ejecución más pobre que el hispano de Zaragoza, de finales del siglo IV, bien estudiado por A. Blanco; sin embargo, es de más calidad artística que el Orfeo y las fieras de la Casa de los Laberii en Oudna. En este mosaico es importante la inscripción que dice: Tito Pinnio Restituto lo hizo. El nombre no es necesariamente el del artesano, ya que podría ser el del dueño de la casa, pero es la única inscripción de este tipo documentada en mosaicos chipriotas.

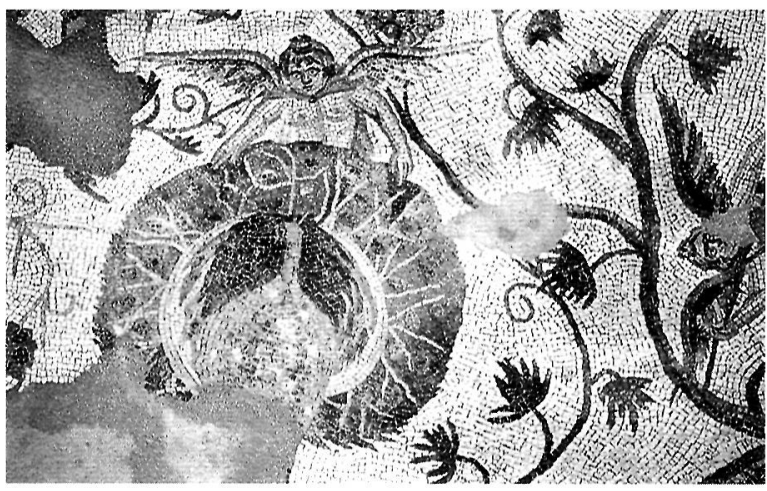

Fig. 17.- Paphos. Casa de Dionysos. Mosaico con Eros y pavo real.

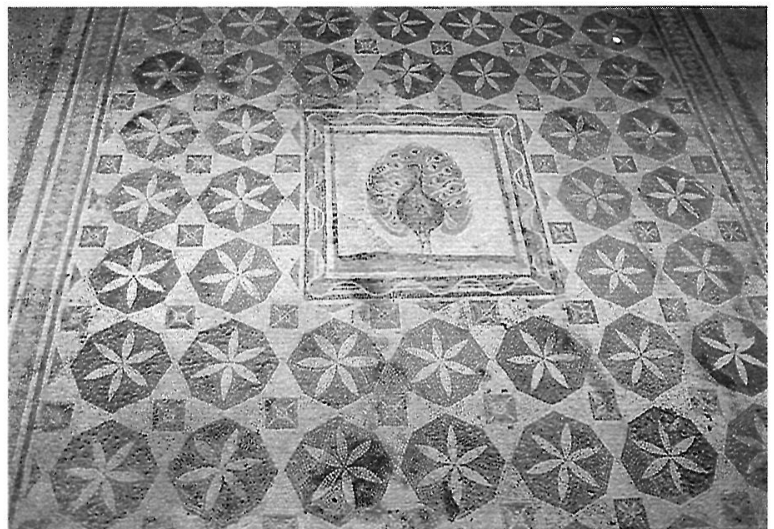

Fig. 18.- Paphos. Casa de Dionysos. Mosaico con pavo real.

Los pavimentos de esta casa siguen el mismo arte que los de la Casa de Dionysos. Algunas tesselas de mármol, de color gris-azul, son importadas, importación que está bien atestiguada en Hispania, como en los mosaicos de Centcelles. Destaca en esta casa un pavimento con una Amazona de pie (fig. 21), delante de un caballo, postura no frecuente en ella y que recuerda a la de los dioscuros de la Casa de Dionysos. Una amazonomaquia se representa en un pavimento de Antioquía y dos amazonas cazadoras en un mosaico de Apamea de Siria, datado en el tercer cuarto del siglo V. Aquiles y Pentesilea se encuentran en un mosaico de Cherchel, de finales del siglo III o de comienzos del siguiente, y en otro de Complutum, en Hispania, de finales de los Severos.

\section{Villa de Teseo}

Recibe el nombre del tema de uno de los mosaicos que decoraban sus habitaciones, fechado en la segunda mitad del

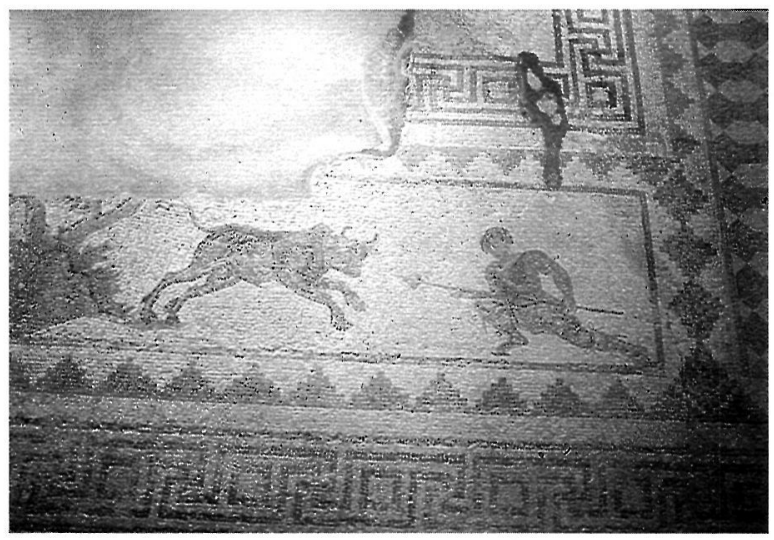

Fig. 19.- Paphos. Casa de Dionysos. Mosaico con escena de caza 


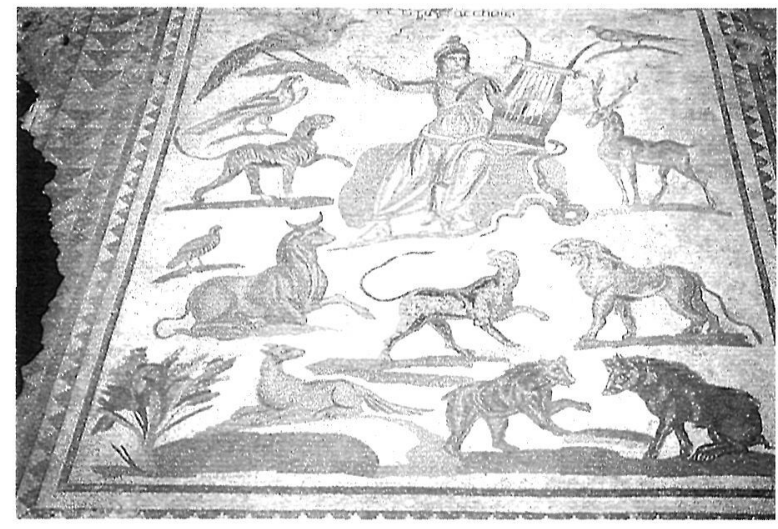

Fig. 20.- Paphos. Casa de Orfeo. Mosaico de Orfeo.

siglo II. La villa se levanta sobre las ruinas de una primitiva casa de época helenística y comienzos de la dominación romana y estuvo habitada por lo menos hasta el siglo VII. La planta de la villa se inspira en las construcciones helenísticas con peristilo. Consta de cuatro alas, ocupadas por habitaciones, alrededor de un gran patio central que tenía un pórtico con columnas al menos en tres de sus lados. El suelo de los tres pórticos estaba cubierto con mosaicos geométricos. El plano de la villa sufrió a lo largo de los siglos, principalmente del IV, importantes transformaciones. La existencia de hermosos mosaicos, de paredes revestidas de mármol, de estatuas también de mármol (Asklepios, cabeza de Isis), la rica decoración, la pintura de las paredes y la presencia de una inscripción redactada en latín, sugieren que el edificio era una villa pública, quizás residencia del gobernador de Chipre, estando bien diferenciada la zona oficial de la particular.

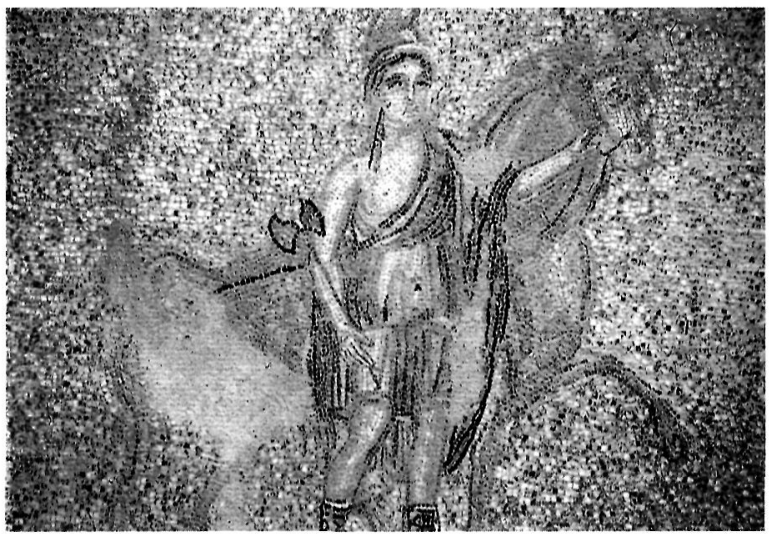

Fig. 21.- Paphos. Casa de Orfeo. Amazona

\section{Teseo y el Minotauro (fig. 22)}

La lucha de Teseo y el Minotauro gozó de gran aceptación entre los temas mitológicos que representaban gustosos los musivarios. W.A. Daszewski al estudiar el tema, con motivo de publicar este mosaico de Nea Paphos, catalogó 62 piezas, a las que hay que añadir alguna más. Africa ha dado 16 mosaicos con el mito de Teseo, e Hispania cuatro (Pompaelo, siglo II; Córdoba, siglo III; Torre de Palma, época constantiniana; y Conímbriga, con el busto del Minotauro dentro del Laberinto).

El mosaico de Nea Paphos es de una gran originalidad aunque representa, como la mayoría de los pavimentos con este mito, a Teseo, joven imberbe colocado de pie, con la clava en alto y sujetando por un cuerno al Minotauro ya caído. El dios del Laberinto está visto como un viejo tumbado en el suelo que contempla asustado el combate, según indica el gesto de su brazo izquierdo, recogido sobre el pecho con la palma de la mano abierta. La lucha se desarrolla delante de una cueva, siendo contemplada por Ariadna y una personificación de Creta, como lo indica la corona torreada, que aparecen en la parte superior recostadas sobre la roca. Todos los personajes van acompañados por sus correspondientes letreros que los identifican. Los materiales de la excavación proporcionan a este mosaico una cronología a finales del siglo III o comienzos del siguiente. Un terremoto acaecido en el siglo IV dañó el mosaico que fue restaurado posiblemente al final de este siglo por un buen artesano, ya que las restauraciones no se aprecian fácilmente. Se rehicieron las cabezas y la parte superior de los cuerpos de Teseo y de Creta y se modificó la zona situada entre ésta y Ariadna. Las figuras de Ariadna y del dios del Laberinto siguen una tradición que se remonta al período helenístico; en cambio, las cabezas de Teseo y de Creta recuerdan el arte de comienzos de época bizantina. Teseo, que ocupa el centro del medallón, carece de pathos que le caracteriza en otros mosaicos. El héroe está colocado en posición

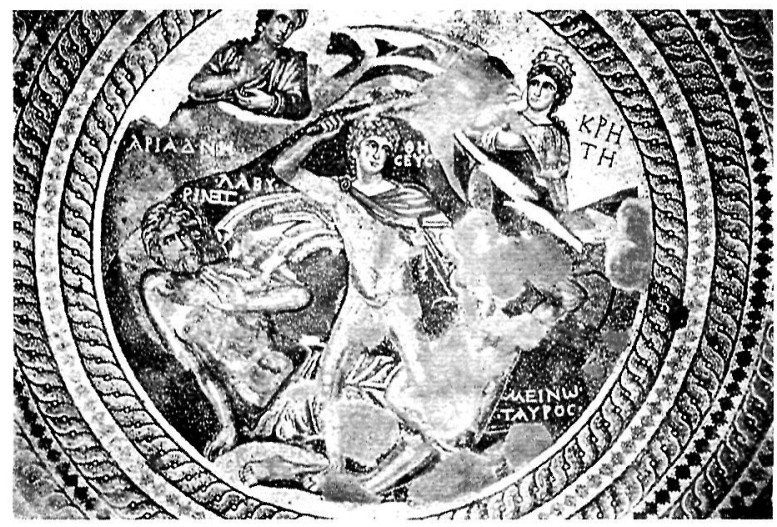

Fig. 22.- Paphos. Villa de Teseo. Teseo y el Minotauro 
frontal, cuando generalmente se encuentra de perfil, como en el mosaico de Córdoba. Llama la atención el gesto de los ojos, dirigidos hacia arriba, como desinteresándose del feroz combate, en una actitud muy peculiar en determinadas figuras del Bajo Imperio. Seguramente Teseo rerpresenta aquí la virtud frente a la fuerza bruta del Minotauro.

\section{Poseidón y Anfitrite}

Un mosaico de esta villa, muy dañado en el momento de su aparición, representa al dios del mar, Poseidón, conduciendo el carro tirado por monstruos marinos, en compañía de Anfitrite. Este mito inspiró fundamentalmente a los musivarios africanos, como se comprueba en los pavimentos de Utica, de finales del siglo II o de comienzos del III; o de Constantina, del segundo cuarto del siglo IV. Un detalle importante en el mosaico chipriota es que encima de la pareja aparecen dos erotes sosteniendo un velo flotante. Esta particularidad se encuentra también en pavimentos africanos, como en el mencionado mosaico de Constantina y en un segundo con el triunfo de Venus marina, recostada sobre un hipocampo en compañía de un joven tritón, que se fecha a finales del siglo II. A juzgar por las monedas halladas, el mosaico de Nea Paphos puede datarse al final del siglo IV, en tiempos de las restauraciones del mosaico de Teseo.

\section{El baño de Aquiles niño (figs. 23-24)}

El mosaico decoraba el suelo del aula principal del palacio, situada en el centro del ala sur, que era probablemente donde se desarrollaban las actividades del gobernador. El suelo estaba revestido de mármol, así como las partes bajas de las paredes, mientras que la parte superior de las mismas se adornaba con murales. Varios mosaicos cubrían el suelo de la habitación, cuyo centro iba decorado por cuatro paneles, de los que se conserva solamente uno con el baño del niño Aquiles. Los tres restantes debían mostrar escenas de la vida del héroe griego, temas que inspiraron frecuentemente a los artistas de la Antigüedad. Baste recordar el mosaico del Museo de Antalya de arte muy degenerado, publicado por nosotros, con la leyenda de Tetis lavando al niño Aquiles en las aguas de la laguna Estigia para hacerle inmortal. El tema se repite en un fragmento de mármol del siglo IV procedente de Egipto, en un plato de Tesalónica de la mitad de este siglo, y en un fragmento de otro plato de procedencia desconocida. Otro episodio de la vida de Aquiles, que probablemente estaría representado en alguno de los paneles de esta habitación es el rapto de Briseida, composición representada en un papiro del siglo IV procedente de Egipto, en donde aparece la concubina de Aquiles acompañada de los heraldos que iban a buscarla. Aquiles, Briseida y los heraldos Taltibio y Euribates figuran, asimismo, en una placa del siglo IV cuyo origen se desconoce.

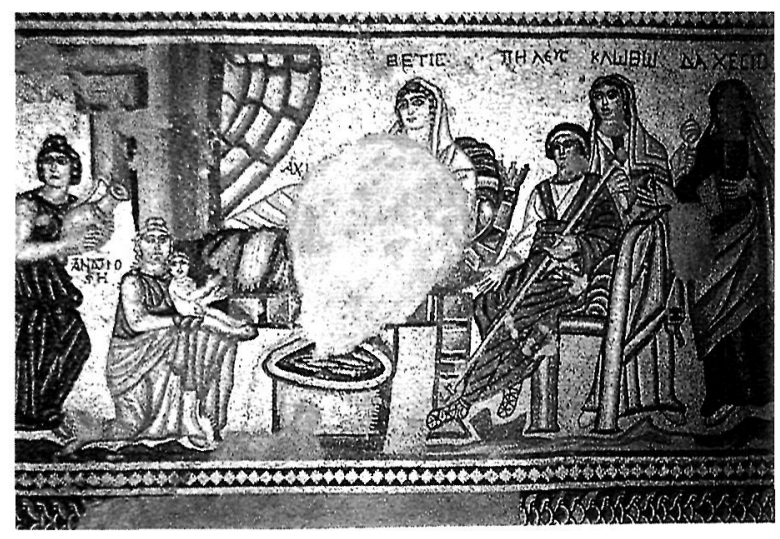

Fig. 23.- Paphos. Villa de Teseo. Baño de Aquiles niño.

Tres escenas de la vida de Aquiles se encuentran en una miniatura de la Iliada Ambrosiana, fechada entre los siglos II y V; en una de ellas Briseida, colocada entre los heraldos, vuelve la vista hacia Aquiles, escena que se repite en la cista Doria, datada en el siglo V y quizás otra egipcia. El mismo tema se vuelve a encontrar en un plato de plata del siglo IV, de procedencia desconocida, que se guarda en la Biblioteca Nacional de París. En un mosaico de Mérida del Bajo Imperio, publicado recientemente por J.M. Álvarez Martínez, debajo de los siete sabios con sus correspondientes letreros, el musivario ha colocado a Briseida, Aquiles, Agamenón y Ulyses. En un mosaico de las termas de Cherchel que representa varias escenas de la leyenda de Aquiles: Aquiles y Gerión, Aquiles en Skyros, Aquiles y Pentesilea, escenas que muy bien podían estar presentes en los paneles de Nea Paphos. También en mosaicos de Tipasa figuran Aquiles en Skyros y Aquiles y Pentesilea. El primer tema se repite en un pavimento de Palmira, de fines del siglo III o

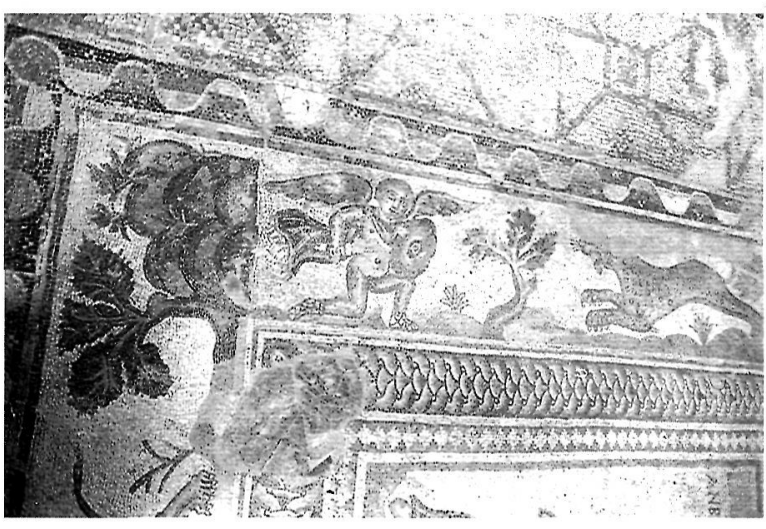

Fig. 24.- Paphos. Villa de Teseo. Baño de Aquiles niño. Detalle de la orla 
comienzos del siguiente, y en una pintura de esta misma ciudad, procedente del hipogeo de los tres Hermanos, importante para ver las relaciones entre pintura y mosaicos. El tema de Aquiles en Skyros fue muy representado en la musivaria romana. En Hispania se encuentra en un pavimento de Pedrosa de la Vega, de época teodosiana, y en otro de Santisteban del Puerto. En África lo tenemos documentado, en los citados mosaicos de Tipasa, de comienzos del siglo IV; de Thysdrus, Casa de Aquiles, de 180-210; y de Cherchel, Casa de las Gracias, de finales del siglo IV.

La versión representada en el mosaico de Nea Paphos difiere de la transmitida en el mito, que es la seguida en el pavimento del Museo de Antalya. En el lado izquierdo, la nodriza Anatrofe, rodilla en tierra, sostiene al niño Aquiles desnudo, que mira al espectador. Anatrofe está colocada de tres cuartos, viste larga túnica y manto. Delante de ella y de la cama, en donde está recostada Tetis, se encuentra el baño de forma cilíndrica preparado para recibir al niño. A los pies de la cama hay una columna y otra más pequeña se ve al fondo de la habitación. Una cortina de anchos pliegues, recogida sobre la columna, indica que la escena tiene lugar en palacio. Detrás de Anatrofe, una joven, de nombre Ambrosía, lleva un jarro de agua. En el lado derecho de la cama aparece Peleo, padre de Aquiles, sentado en un trono. Viste túnica y manto, estando indicado su status real mediante la banda que ciñe las sienes y el cetro que sostiene en su mano izquierda. A la espalda de Peleo se encuentran las tres Parcas Clotho, Laquesis y Atropos, vestidas con túnica larga y manto. Clotho sostiene en sus manos el huso y la rueca, Laquesis un díptico y Atropos un rollo abierto en el que está escrita la vida de Aquiles. Todas las figuras van acompañadas de su correspondiente letrero que las identifica. Se fecha en el siglo V. Este mosaico chipriota recuerda al del baño del niño Alejandro de Baalbeck, de finales del siglo IV, donde también los personajes llevan letreros que los identifica. La importancia del mosaico chipriota radica, como nos indicó W.A. Daszewski, en el hecho de que constituye un lejano prototipo de las representaciones de Navidad y del primer baño de Cristo, tal como aparecen en mosaicos y pinturas bizantinas y medievales.

La calidad artística de este mosaico es floja. El musivario usa el color para dar la sensación de volumen, pero no logra la perspectiva al no diferenciar bien las figuras colocadas en primer y segundo plano. La impresión que produce el cuadro en el espectador es de hieratismo y solemnidad. Estilísticamente el mosaico se diferencia de los restantes de la villa probablemente por ser de otra época. Sin embargo, no tiene el estilo bárbaro típico de las regiones periféricas del Imperio Romano, cuando las formas artísticas se descomponen, del que son buen exponente los mosaicos hispanos de Estada (Zaragoza), con atleta vencedor, y de Santisteban del Puerto (Jaén); o de la sinagoga palestina de Beth Alpha, con el sacrificio de Isaac o con Helios sobre su cuádriga. Este proceso de descomposición de las formas artísticas de la Antigüedad clásica, que tiene lugar a fines del Bajo Imperio, ha sido bien estudiado por R. Bianchi-Bandinelli, A. Carandini y J.M. Blázquez.

\section{Casa de Aión}

Recibe el nombre de la figura del mosaico de la habitación principal de la casa, Aión, personificación del tiempo. La imagen de Aión decoró gran número de mosaicos romanos, habiendo varios ejemplos en Antioquía, Aión, en compañía de Ge y de Prometeo, se encuentra en el célebre mosaico sirio de Philippopolis, fechado en la segunda mitad del siglo III. La personificación de Aión está presente en pavimentos del África Proconsular, como Haidra, en compañía del Zodiaco, datado a fines del siglo III o comienzos del siguiente; Silin, en la Cirenaica, con Aión y las estaciones, éstas entre el signo del zodiaco sostenido por aquel; Sentinum, en Italia, con Aión dentro del anillo del zodiaco, versión que se repite en la páte-

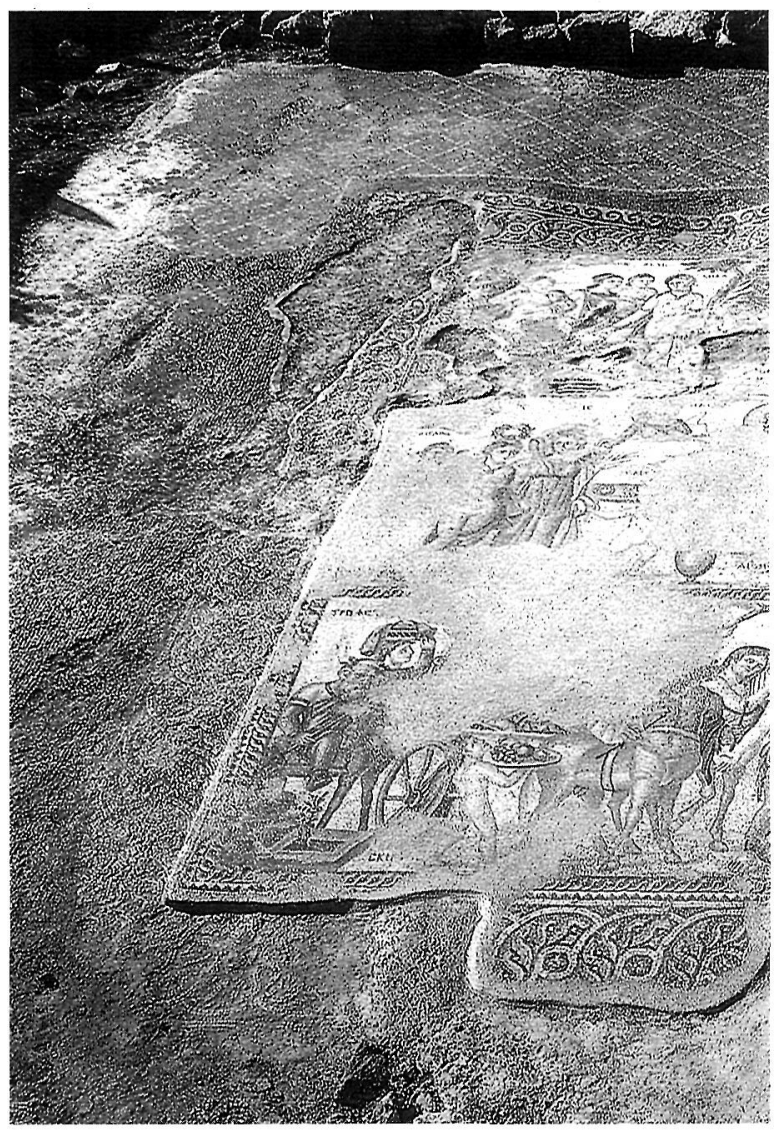

Fig. 25.- Paphos. Casa de Aión. Mosaico de Aión en el momento de su descubrimiento. Parte izquierda. 


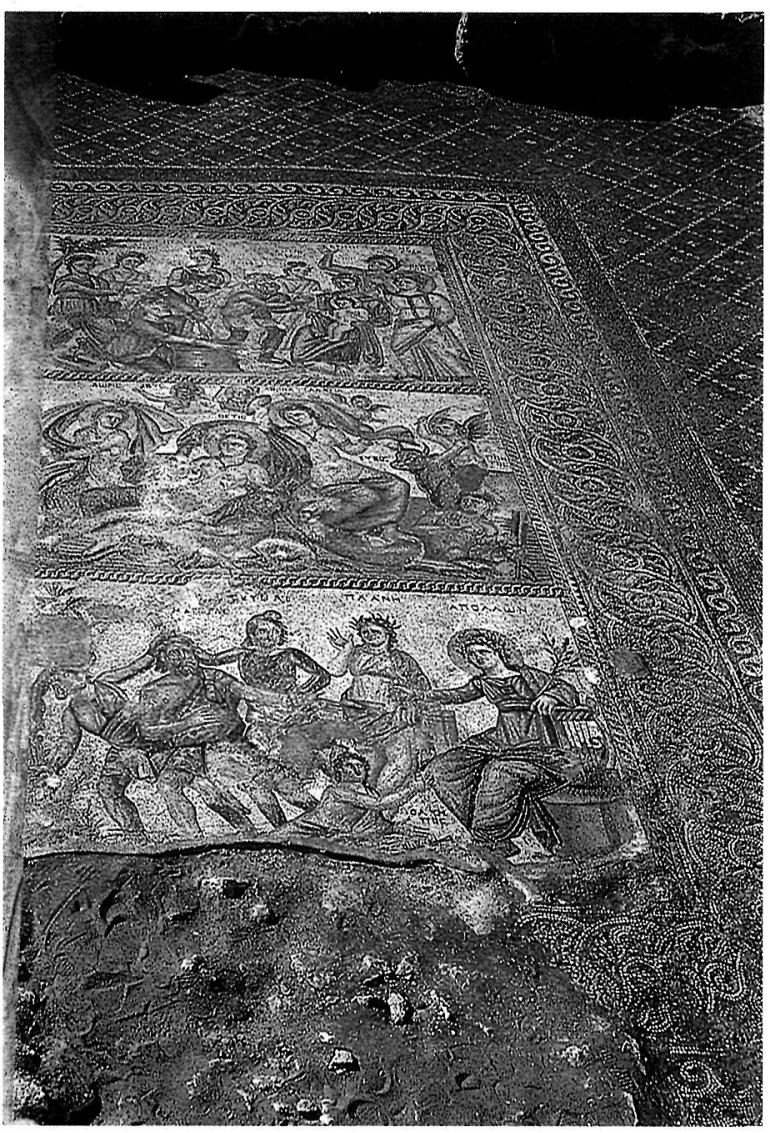

Fig. 26.- Paphos. Casa de Aión. Mosaico de Aión en el momento de su descubrimiento. Parte derecha.

ra hispana de Parabiago. En Hispania es muy probable, como indica M.I. Musso, que la imagen de Aión ocupara el centro del mosaico cosmogónico de Mérida, cuyo sentido mitraico ha sido señalada por J.M. Blázquez, Ch. Picard, A.M. Canto, J. Alvar y D. Fernández Galiano, fechado en época de los Antoninos.

La habitación más amplia de la casa parece haber estado dedicada a hall de recepción. El suelo está cubierto con un gran mosaico dividido en cinco paneles (figs. 25-26), siendo el central un friso corrido, decorado con escenas mitológicas de la más alta calidad artística dentro de la musivaria romana. La costumbre de compartimentar el campo del mosaico está documentada en los citados pavimentos hispanos de las cuatro estaciones de Comunión y de Complutum, así como también en un mosaico de Torre de Palma, cuya superficie de forma rectangular se halla dividida en varios paneles en donde se representan escenas mitológicas. En África, un mosaico de Saint Leu, el antiguo Portus Magnus, del siglo IV, presenta también compartimentos con escenas mitológicas. El pavi- mento de Henchir Toungar, datado en el segundo cuarto del siglo IV, consta de tres paneles superpuestos con escenas de caza. Famoso es un mosaico de la Casa de los Caballos de Cartago, del 300-320, con paneles que contenían un caballo, aurigas y auxiliares del circo. Escenas superpuestas aparecen en otros mosaicos, como en el citado de Tipasa, con la leyenda de Aquiles en Skyros.

\section{Mosaicos (figs. 27-32)}

El pavimento de la Casa de Aión es de una gran finura de ejecución y colorido. Todos los temas mitológicos representados en los cinco paneles son de carácter mitológico. Comenzamos la descripción por la parte superior derecha. Se representa a Dionysos niño, desnudo y con nimbo, sentado en las rodillas de Hermes, que también se encuentra sentado y que es fácilmente reconocible por las alas que lleva en la cabeza y en los tobillos (fig. 27). Trofeo, el futuro tutor de Dionysos se dirige hacia el niño en actitud de recibirlo. Las ninfas del monte Nysa preparan el baño, mientras que detrás la propia Nysa y Anatrofe, la niñera, aparecen sentadas. Al niño Dionysos le acompañan las personificaciones de Teofonía, Nectar y Ambrosía, el divino alimento que proporciona la inmortalidad. Teogonía personifica el nacimiento de los dioses. Los vestidos de todos los personajes que participan en la escena son lujosos y están magníficamente logrados, indicando una gran pericia en la mano del musivario. Coronas de hojas ciñen las cabezas y joyas diversas adornan los brazos de las damas. Sólo dos figuras se desmarcan de las demás, Nysa que lleva diadema sobre la cabeza, y Trofeo que viste túnica corta. Todos los personajes, como en el resto de los paneles, van acompañados de su correspondiente letrero identificador. Piensan W.A. Daszewski y D. Michaelides que este cuadro no es una escena mitológica corriente de la juventud de Dionysos.

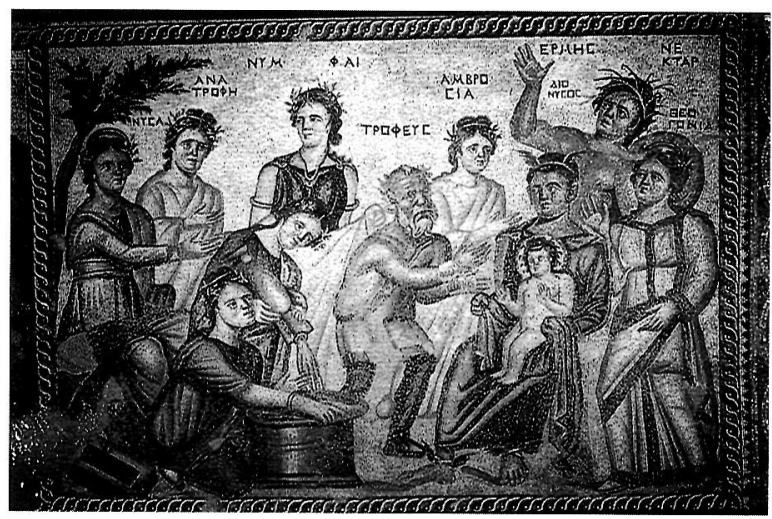

Fig. 27.- Paphos. Casa de Aión. La presentación de Dionysos niño. 


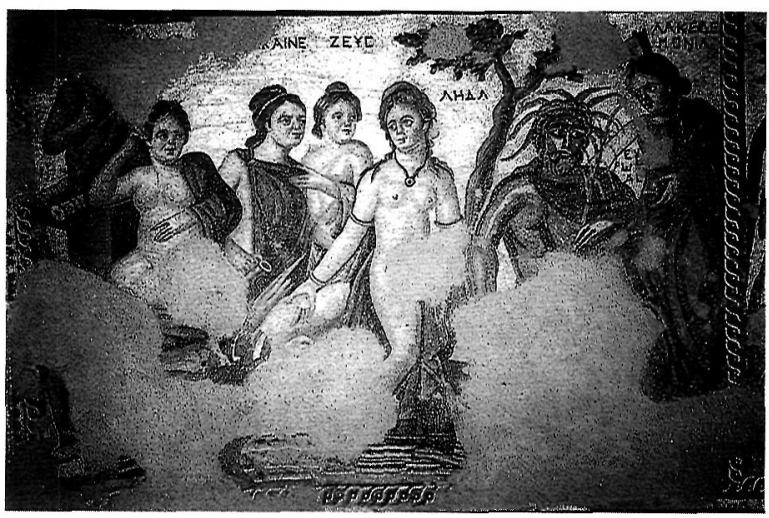

Fig. 28.- Paphos. Casa de Aión. Leda y el cisne.

En el panel superior izquierdo Leda, reina de Esparta y esposa de Tindareo, se encamina desnuda, con diadema en la cabeza y joyas en el cuello, muñecas y brazos, al baño en el río Eurotas, en compañía de jóvenes espartanas (fig. 28). Zeus se le acerca metamorfoseado en cisne. En el lado izquierdo se ha representado un altar y un sátiro con piel de pantera sobre sus hombros, sosteniendo un pedum o una doble flauta.

El panel central es doble y en él se representan dos escenas, una en el mar y otra en tierra. Ambas ilustran la competición entre Casiopea y las Nereidas, hijas de Nereo, dios del agua. Casiopea, famosa por su belleza, era según una leyenda la esposa de Cefeo, que mandaba en Etiopía, y madre de Andrómeda. Según otra versión, era la esposa de Fenix, rey de Sidón o de Tiro. El mosaísta ha elegido esta segunda versión presentando a Casiopea desnuda, en posición frontal, para ser sometida a juicio (fig. 29). Krisis la corona, mientras Aión, juez de la competición, aparece sentado en el centro de la

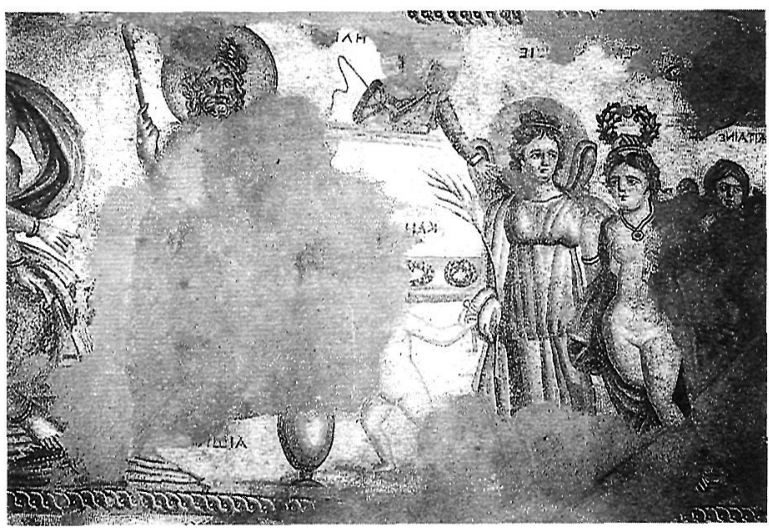

Fig. 29.- Paphos. Casa de Aión. Casiopea y las Nereidas. Detalle de Casiopea.

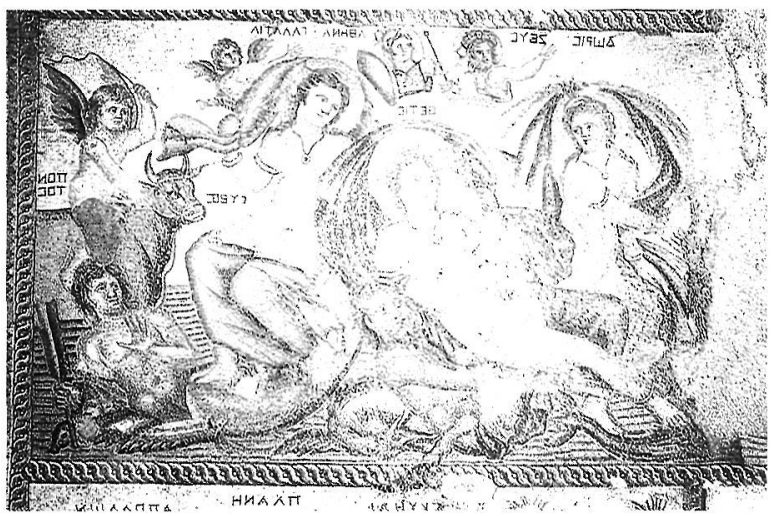

Fig. 30.- Paphos. Casa de Aión. Casiopea y las Nereidas. Detalle de las Nereidas.

composición empuñando el cetro en la mano derecha. Una corona de hojas ciñe su cabeza nimbada. El joven Cairos, personificación del momento oportuno, asiste al juicio. En la parte superior del cuadro Helios, dios solar, y posiblemente Selene, diosa lunar, hoy perdida, se disponen a recibir a Casiopea. La escena marina representa a las hijas de Nereo, Tetis, Doris y Galatea, famosas por su belleza (fig. 30). Las tres van semidesnudas con el velo arqueado sobre sus cabezas. Los rostros expresan de forma magnífica la desilusión ante el resultado de la competición. A Tetis, colocada en el centro de las tres, la sostiene el centauro marino Bytos, cuya cabeza está coronada con pinzas de cangrejo. El joven Ponto contempla atónito a las tres hijas de Nereo, portando un remo en su mano izquierda. En la parte superior de la composición se encuentran Zeus y Atenea. A la derecha, Eros cabalga un toro.

El panel inferior derecho va ilustrado con la leyenda de la disputa entre Apolos y Marsias (fig. 31), escena representada de forma muy bárbara en el mosaico hispano de Santisteban

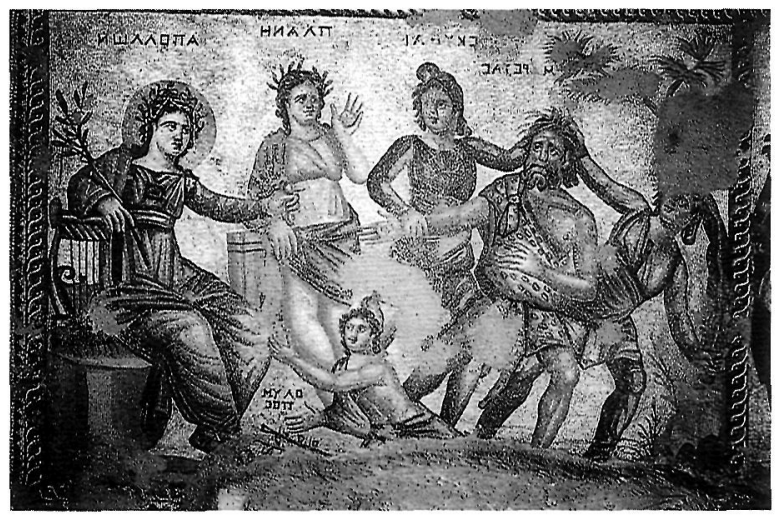

Fig. 31.- Paphos. Casa de Aión. Apolo y Marsias 


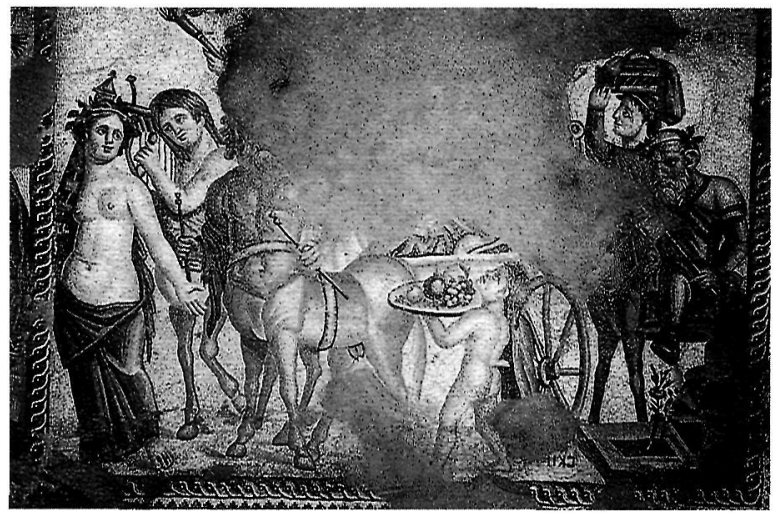

Fig. 32.- Paphos. Casa de Aión. Triunfo de Dionysos niño.

del Puerto. Apolo aparece sentado apoyado en la cítara y sosteniendo en la mano izquierda el ramo de laurel. Marsias, cubierto con piel de pantera, es conducido por dos escitas tocados con gorro frigio para ser desollado por haber osado competir con el dios de las artes. El artesano ha sabido plasmar de forma excelente el horror en el rostro de Marsias ante la proximidad del castigo. Precisamente todos estos mosaicos chipriotas se caracterizan por las actitudes psicológicas bien reflejadas en los rostros, por la calidad lograda en el estudio de la anatomía humana, por el minucioso acabado de los vestidos y por el movimiento de la escena. Junto a Apolo se encuentra Plane y delante Olimpos implorando la benevolencia del dios.

En el panel inferior izquierdo el joven Dionysos recorre en procesión el mundo sobre un carro tirado por dos centauros, uno de ellos tocando la lira (fig. 32). En primer plano, un pequeño sátiro desnudo ofrece a Dionysos una bandeja con frutas, uvas, granadas y manzanas. El viejo tutor, Trofeo, acompaña al dios montado en una mula. Detrás del carro, aparece una joven con un cesto sobre la cabeza. En el lado derecho abre la procesión una joven semidesnuda llevando una antorcha y coronada por hojas. Aunque gran parte del mosaico se ha perdido, no se puede negar cierto aire religioso en toda la escena, bien indicado en el hecho de que todos los personajes que intervienen miran al dios. Tanto K.M.D. Dunbabin como A. Blanco no descartan este sentido religioso en algunos mosaicos dionisiacos. Concretamente A. Blanco piensa que en los pavimentos hispanos de Tarragona o de Annius Ponius de Mérida parece estar implícita la idea de deificación del devoto o de asimilación al dios. Al igual que en los restantes paneles, todas las figuras llevan su nombre.

Las escenas figuradas de este mosaico de la Casa de Aión se prestan a algunas consideraciones. El niño Dionysos, en brazos de Hermes, es tema muy poco frecuente en la musivaria. En Hispania no se documenta ni una sola vez, mientras que en el norte de África tan sólo en un mosaico de Djemila, fechado en el segundo o tercer cuarto del siglo II, aparece el niño Dionysos cuidado por las ninfas. Sí se encuentra el mismo tema en un pavimento de Antioquía, pero con Hermes de pie llevando al niño en brazos. Muy frecuente es, por el contrario, la representación de Leda, especialmente la escena del baño; y rara la leyenda de Casiopea que aparece en un mosaico de Palmira de finales del siglo III o de comienzos del siguiente. La escena de las tres hijas de Nereo, juntas, tampoco es corriente, siendo lo normal representar sólo a Tetis, como en el mosaico de Jaén y en varios africanos: ZiamaMansouriah, con la boda de Peleo y Tetis, que se repite en la Casa de las Tres Gracias de Cherchel, fechado entre los años 320-340, etc.; o a Galatea, como en el mosaico hispano de Ilici y en los pavimentos de las termas de Themetra, del 200-220, o de Thysdrus con Polifemo y Galatea, fechado entre los años 180-200, o de Córdoba, en torno al 200, con el mismo tema. Las hijas de Nereo sostenidas por monstruos marinos y con el velo arqueado flotando al viento, siguen un modelo bien conocido, como se ve en los mosaicos con el triunfo de Venus de Timgad y de Bulla Regia, este último de la mitad del siglo III.

La pompa triumphalis báquica de la Casa de Aión ofrece algunas particularidades. El carro dionisiaco tirado por centauros se encuentra en mosaicos de Acholla, entre los años 115-120, y de Thysdrus, del 200-220, aquí también con lira uno de los centauros. En Hispania se documenta en un pavimento de Alcolea (Córdoba), fechado entre los años 160-170. En relieves de sarcófagos son frecuentes los carros dionisiacos tirados por centauros, como en los ejemplares de Pisa, del 200; del Museo Torlonia, de Roma, de época del emperador Marco Aurelio; del Museo del Louvre, fechado entre los años 230-240, etc. La competición entre Apolo y Marsias es también un tema frecuente en mosaicos africanos: Portus Magnus, del siglo IV; Thysdrus, entre los años 180-200, etc.

Piensan los autores que han publicado estos excepcionales mosaicos de la Casa de Aión, que es probable que los cinco paneles tengan un programa común con un mensaje definido. La primera y la última escena son dionisíacas. La primera proclamaría la epifanía de Dionysos, corroborada por la presencia de las tres personificaciones, dos de ellas vinculadas con la inmortalidad. La última leyenda alude a su triunfo, teniendo un especial significado la cesta que es utilizada en la iniciación de los misterios. La historia de Leda haría referencia a los designios de los dioses. La competición entre Casiopea y las Nereidas simbolizaría la pugna entre la naturaleza salvaje, representada por el mar, y el divino orden cósmico, al convertirse Casiopea en constelación después de su muerte. El mismo significado tendría el enfrentamiento entre Marsias y Apolo.

El mosaico se fecha en la mitad del siglo IV, cuando ya el cristianismo había dado un gran avance en la parte oriental del Imperio Romano. No obstante, todavía pervivía una vieja aristocracia, como el dueño de la Casa de Aión, apegada a su anti- 
gua mitología, clase bien representada por Juliano, Pretestato, Macrobio y Simmaco.

\section{MOSAICOS FIGURADOS Y GEOMÉTRICOS}

\section{Mosaicos figurados}

En el trabajo anterior recogíamos todos los mosaicos procedentes de la ciudad romana de Nea Paphos, porque considerábamos que formaban un conjunto tanto por su número como por su común lugar de origen. En el presente artículo agrupamos el resto de los mosaicos figurados, dignos de ser recordados, que provienen de distintos sitios arqueológicos de Chipre: Paleapahos, Kourion, Alassa, Lamboussa, Mansoura y Kition.

\section{Leda y el cisne (fig. 33)}

En Kouklia, la antigua Paleapaphos, a unos pocos cientos de metros del ángulo noroeste del famoso templo de Afrodita, se descubrió en 1971 un mosaico que decoraba el triclinium de una casa. Interesa la parte central que representa a Leda de espaldas, caminando semidesnuda sobre las aguas. El manto se enrolla en el brazo izquierdo y cae cubriéndole la parte inferior del cuerpo. A su izquierda se encuentra el louterion junto a un árbol: en el lado derecho se ve una pilastra coronada por objeto circular. Entre ésta y la dama, que sujeta el extremo del manto con su mano derecha y vuelve la cabeza de perfil hacia este lado, se encuentra el cisne, visto de perfil y con el cuello vuelto hacia ella. La leyenda de Zeus convertido en cisne para

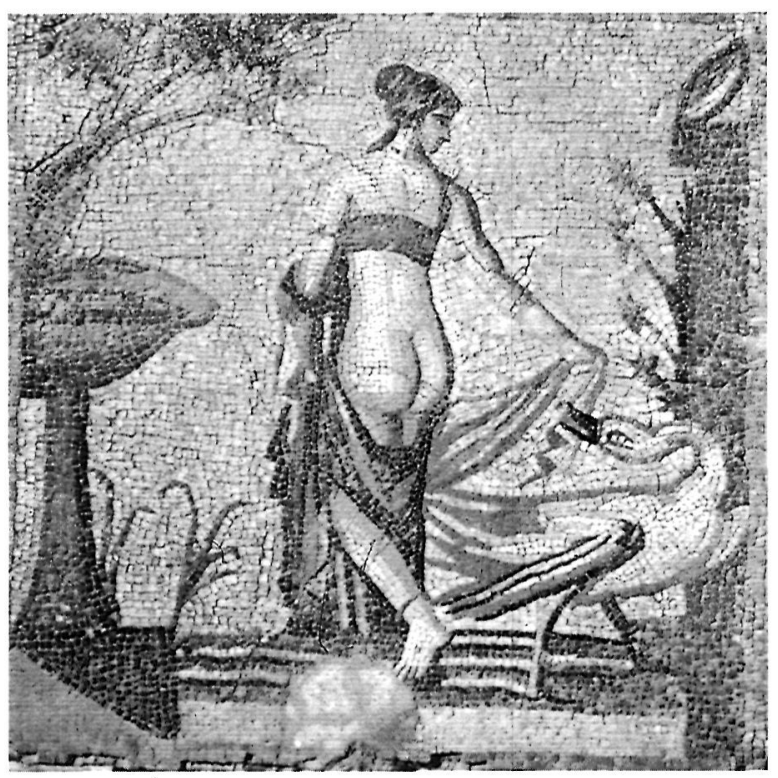

Fig. 33.- Kouklia. Leda y el cisne. poseer a Leda, hija del rey de Etolia y esposa de Tindareo, gozó de gran favor entre los escritores antiguos, como Homero, Apolonio de Rodas, Eurípides, Virgilio, etc., y aparece frecuentemente representada en los mosaicos romanos. Baste recordar en Hispania los pavimentos bajoimperiales de Complutum y Quintanilla de la Cueza, y el italicense de los Amores de Zeus, datado en la segunda mitad del siglo II. En África este mito está documentado en mosaicos de Ouled Agla, con el mismo tema de los Amores de Zeus, de comienzos del siglo IV; de Lambaesis; de Thysdrus, entre 220 235, etcétera.

W.A. Daszewski y D. Michaelides, al publicar esta pieza, que en la actualidad se conserva en el Museo Arqueológico de Nicosia, escriben que es una representación de Leda no frecuente y ponen en relación la postura de la reina de Esparta con la de una de las Tres Gracias, o con la figura de Flora de una pintura de Stabies, del siglo I; y también con la imagen de Castalia de un mosaico de Nabeul, en donde aparece en compañía de dos ninfas y de Pegaso, fechado a comienzos del siglo IV. Efectivamente, la postura de Leda, de espaldas, es la misma que la de una de las Tres Gracias del mosaico de Karli Kuyu, en el que la Gracia central se cubre también los senos, con una banda. Otras representaciones de la Gracia central en idéntica postura son las de los mosaicos de Cherchel, Sabratha, Barcelona y Fuente Alamo (Córdoba), que remontan a un prototipo en pintura, como la de las Tres Gracias de Pompeya. Los pavimentos hispanos de Leda y el cisne se aproximan en algunos detalles al mosaico chipriota. El de Complutum muestra a Leda caminando desnuda en posición frontal y sujetando el manto exactamente igual que la Leda de Paleapaphos. Como los mosaicos chipriotas, también éste se acompaña de letreros y se fecha a fines del siglo IV o comienzos del siguiente.

En opinión de Killey Kahil, el pavimento de Kouklia representaría a Afrodita y al cisne, pero creemos que la identificación con Leda y Zeus parece más aceptable. El mosaico se fecha a comienzos del siglo III y está fabricado con tesselas de procedencia local.

\section{Aquiles en Skyros (fig. 34)}

La Casa de Aquiles, en Kourion, ha proporcionado un bello mosaico que decoraba el pórtico columnado situado al nordeste de un patio abierto con habitaciones a cada lado. La escena representa uno de los episodios de la vida de Aquiles, su estancia en Skyros. La leyenda, recordada por Apolodoro y Ovidio, cuenta cómo Aquiles, para escapar al destino de morir si participaba en la guerra de Troya, según le había pronosticado el oráculo, fue enviado por su madre Tetis a la corte de Licomedes, rey de Skyros, quien le ocultó entre sus hijas disfrazado de mujer.

El mosaico muestra el momento en el que el héroe griego es descubierto por el astuto Ulises al ofrecerle unas armas. 


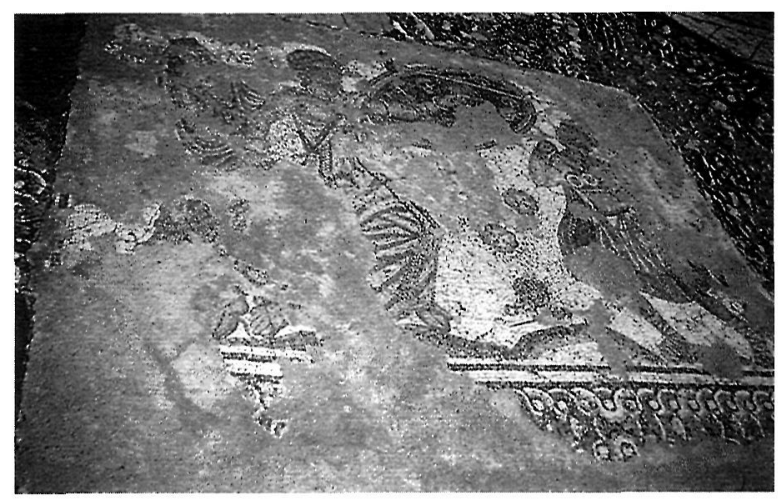

Fig. 34.- Kourion. Casa de Aquiles. Aquiles en Skyros.

Aunque muy dañado, el pavimento conserva las figuras de Ulises a la derecha, Aquiles vestido con ropas femeninas en el centro, y a la izquierda Deidameia, una de las hijas de Licomedes con la que el héroe griego tuvo un hijo. Todas las figuras van acompañadas de un letrero que las identifica. Entre Aquiles y Ulises se ven dos flores cuatripétalas y el huso tirado en el suelo; en la parte superior del mosaico se ha representado una trompeta. Es digno de señalarse que el interior del escudo sostenido por Aquiles va decorado con pequeñas campanillas para llamar a la batalla, detalle éste que no es frecuente. El pavimento, que se caracteriza por la excelente ejecución del movimiento de las figuras y por la intensidad del colorido, muy bien logrado, se fecha en el siglo IV. El tema de Aquiles en Skyros aparece en dos mosaicos hispanos de Santisteban del Puerto (Jaén) y Pedrosa de la Vega (Palencia), ambos del Bajo Imperio. El mosaico palentino representa una composición más recargada en figuras y en elementos arquitectónicos que representan el gineceo. En el centro de la composición se encuentra Aquiles y a su izquierda Ulises, mientras que el ángulo superior está ocupado por dos soldados. La esposa de Licomedes preside la escena que representa el momento en que Aquiles se sorprende ante el ruido de las trompetas de guerra. Deidameia sujeta al héroe por la cintura y dos de sus hermanas le cogen por las piernas para impedir que se marche. En la parte inferior se han representado unas cestas tiradas por el suelo, de las que salen un peine, un huso y lanas. El tema gozó de una gran aceptación a lo largo de todo el mundo clásico pues, según Pausanias, ya lo pintó Polignoto en la Pinacoteca de los Propileos de Atenas, y en el siglo IV a.C. Athenion de Meronea, al decir de Plinio.

Distintos episodios de la vida de Aquiles inspiraron frecuentemente a los musivarios romanos. A ellos se ha aludido en el trabajo anterior, dedicado a los mosaicos de Paphos, y aún pueden recordarse muchos más.

\section{Rapto de Ganímedes (fig. 35)}

En otra habitación de esta misma casa se conserva, en pésimo estado, un pavimento que representa el rapto de Ganímedes por Zeus metamorfoseado en águila. Una ancha franja, decorada con motivos geométricos de dobles peltas en líneas alternadas, bordean el emblema central. Las excavaciones proporcionan unas fechas en el siglo IV. Al parecer, se trata de un edificio público, y no de una casa privada, en donde eran recibidos los visitantes ilustres.

\section{Combates de gladiadores (figs. 36-37)}

En la misma localidad de Kourion la Casa de los Gladiadores ha dado dos excelentes mosaicos figurados. En uno de ellos (fig. 36) se representa la lucha de una pareja de gladiadores, colocados de perfil, que aparecen protegidos por sus correspondientes escudos, llevan espada en la mano y casco de visera que les cubre el rostro. Visten el traje típico de los gladiadores, que deja al descubierto los brazos y parte de las piernas. Este se compone de ancho cinturón o balteus, subligaculum y fasciae para proteger las piernas: una pieza de forma triangular, galerus, refuerza la protección de los hombros e indica que se trata del combate de dos retiarios. Toda la vestimenta está realizada con sumo detalle y vivos colores. Cada gladiador va acompañado de su correspondiente letrero indicando el nombre. Uno se llama Hellenicos, siendo la primera vez que se atestigua como nombre de gladiador; y su contrincante, Margareites, documentado como nombre de gladiador en Roma y Afrodisias.

El segundo mosaico (fig. 37) introduce una novedad con la representación, entre la pareja de gladiadores, de la figura del lanista, de nombre Dareios, según indica la inscripción. Otro letrero identifica al combatiente de la izquierda como Lytras, habiéndose perdido casi del todo el situado en el lado

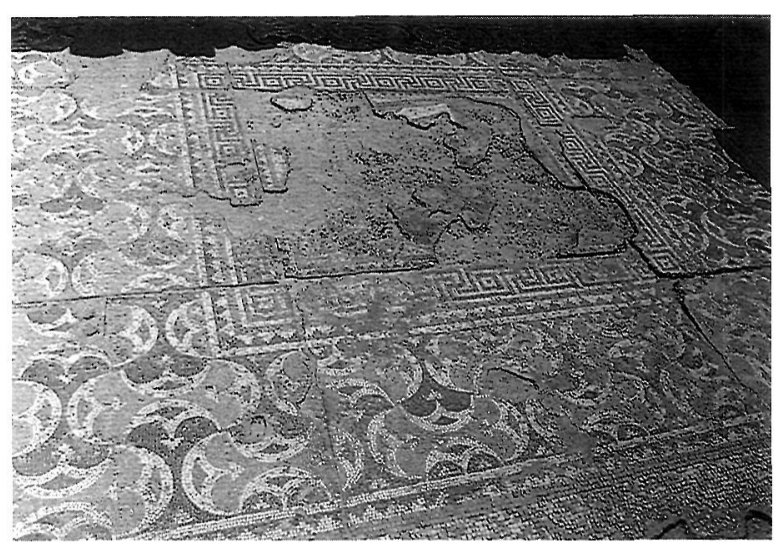

Fig. 35.- Kourion. Casa de Aquiles.Rapto de Ganimedes. 


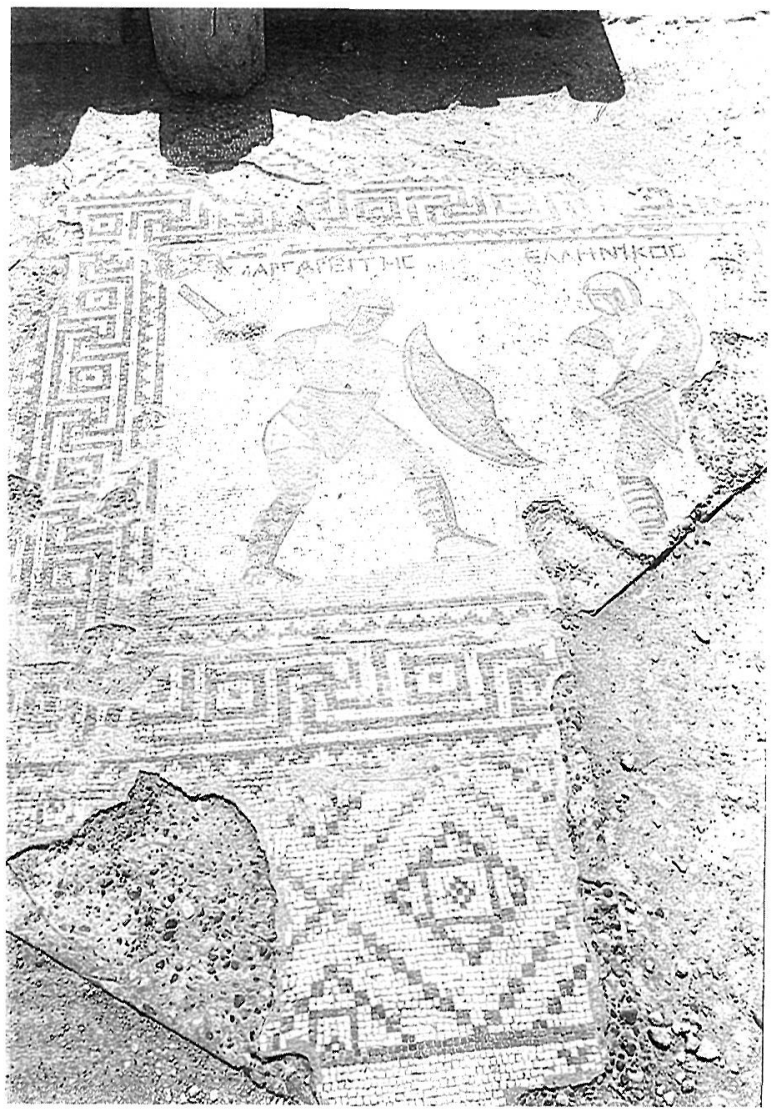

Fig. 36.- Kourion. Casa de los Gladiadores. Mosaico de Margareites y Hellenicos.

derecho, cuyo nombre comenzaba por E... Lytras protege su cabeza con el yelmo o galea y se defiende con puñal curvo y un gran escudo rectangular. Un ancho balteus le ciñe la cintura. Protege sus piernas con ocreae de placas de metal. Lytras pertenece a una clase de gladiador llamado thrax por el tipo de puñal curvo que utiliza. Una manica protege su brazo derecho, desde el hombro hasta la mano. Es imposible precisar quien era su contrincante, que solía ser un oplomachus o un murmillo. El lanista supervisaba el encuentro.

Ambos combates están representados con gran realismo y viveza, estando bien expresada en la actitud de los cuerpos la sensación de ataque de defensa y de expectación ante la acometida del adversario. Los colores empleados son de tonalidades fuertes. Estos dos excepcionales mosaicos se fechan, por los datos suministrados por la excavación, en la segunda mitad del siglo III.

La lucha de los gladiadores es un tema representado frecuentemente en mosaicos. Baste recordar, por citar sólo los más conocidos, los pavimentos de Zliten, con el mismo tipo

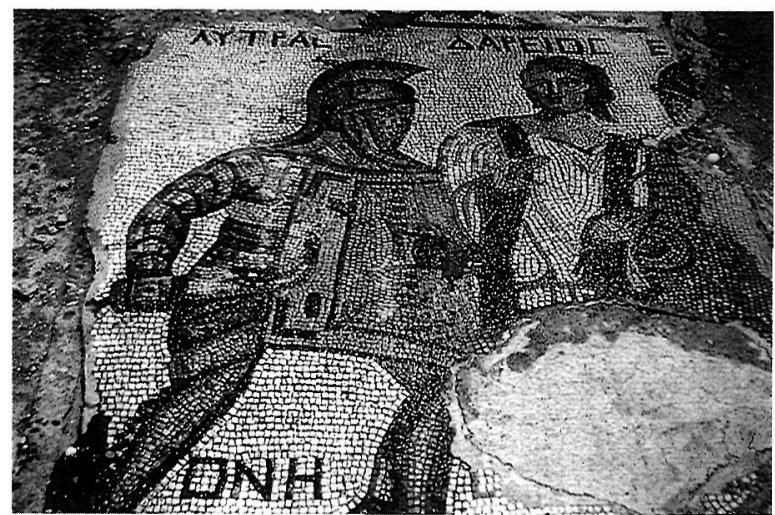

Fig. 37.- Kourion. Casa de los Gladiadores. Mosaico de Litras y Dareios.

de escudo y cascos de plumas, de cronología discutible, ya que para unos es de época flavia y para otros del siglo III; de la Galería Borghese de Roma, procedente de Torre Nuova, donde los gladiadores van acompañados también de sus nombres; del Museo Arqueológico Nacional de Madrid, procedentes de Roma, igualmente identificados por los letreros, etc. Combates de gladiadores decoran los laterales de un mosaico conservado en el Museo Arqueológico de Estambul y una buena colección de gladiadores, procedentes de las Termas de Caracalla en Roma, se conservan en el Museo Laterano. Este tipo de combates son de origen etrusco y se celebraban, en principio, el día del sepelio de personajes importantes. Se representan por primera vez en pinturas de la Tumba de los Augures en Tarquinia, fechadas en torno al 590 a.C. En tumbas de Paestum, del siglo IV a.C., se pintaron frecuentemente combates de gladiadores como parte del ritual funerario. Escipión el Africano celebró en Hispania en el año 209 a.C., después de la conquista de Carthago Nova, estos combates en honor de su tío y de su padre muertos pocos años antes (211212 a.C.) por la traición de los celtíberos, según testimonio de Zonaras $(9,10,3)$. Luchas de combatientes, en número de doscientas parejas, según el historiador Diodoro $(33,21)$, se celebraron sobre el túmulo de Viriato con ocasión de sus funerales. Los combates de gladiadores gozaron de gran aceptación en el Oriente, habiendo catalogado L. Robert muchas representaciones de ellas o inscripciones alusivas a estos combates.

\section{Mosaico con aves y peces (fig. 38)}

Al Este del teatro de Kourion se encuentra la Casa de Eustolios cubierta por gran número de mosaicos, entre los que destaca uno de gran belleza y vivos colores, decorado con figuras de aves y peces dentro de recuadros. El campo del mosaico presenta una decoración geométrica formada por 
cuatro cruces de Malta curvilíneas entrelazadas mediante cable de dos cabos que dejan cuatro cuadrados de damero en los ángulos. En el centro de la composición y en los cuatro lados van cinco paneles rectangulares ornados con tres aves y dos peces. Este tema, como motivo decorativo, gozó de gran aceptación en el Bajo Imperio. Baste citar en Grecia los mosaicos de las basílicas de Nikópolis y de Anfípolis, del siglo $\mathrm{V}$, en donde alternan peces y aves dentro de recuadros, exactamente igual que en el pavimento chipriota. También en Occidente es frecuente el empleo de aves y peces como motivo decorativo, siendo un ejemplo los mosaicos hispanos de Villavidel (León), San Martín de Losa (Burgos) y Segura de la Sierra (Jaén). Todo lo cual indica que en el Bajo Imperio existía una comunidad artística entre Oriente y Occidente, aunque los temas fueran tratados de diferente forma. El mosaico de Kourion se fecha en tiempos de Teodosio II (408-450).

\section{Ktisis (figs. 39-40)}

La Casa de Eustolios alberga también unas pequeñas dependencias termales, cuyos suelos están decorados con ricos pavimentos. El frigidarium es una gran sala rectangular cubierta con cuatro mosaicos, uno de los cuales va adornado con una perdiz dentro de un cuadrado central. Otro representa un busto femenino colocado de frente, aunque con la cabeza vuelta ligera hacia el lado derecho. Viste túnica que deja al descubierto el brazo derecho, doblado, cuya mano sostiene una varilla que mide un pie romano y que es su atributo. El cabello, muy abultado, desciende hasta los hombros peinado a ondas. La inscripción que acompaña a la figura indica que se trata de una representación de Ktisis. Esta práctica de identificar a las figuras mediante letreros se generaliza en los mosaicos romanos a partir del siglo III. Destaca en la realización de esta figura la expresión un tanto melancólica del rostro, siendo precisamente una característica de los mosaicos chipriotas el lograr de

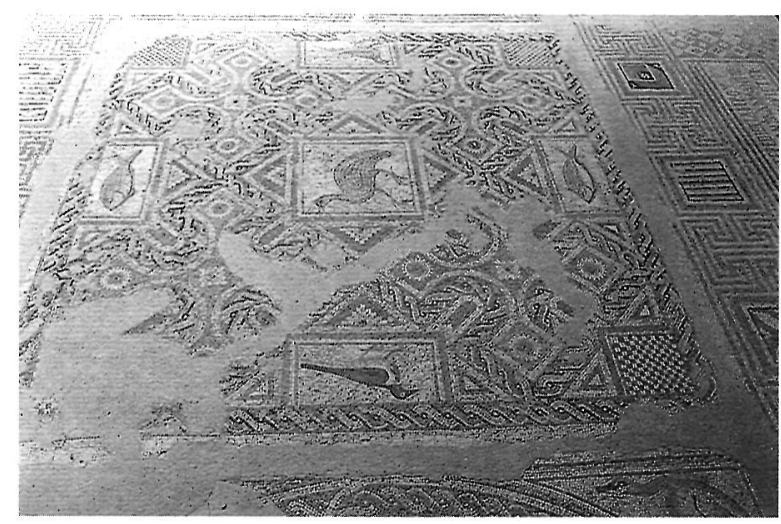

Fig.38.- Kourion.Casa de Eustolios.Mosaico con aves y peces.

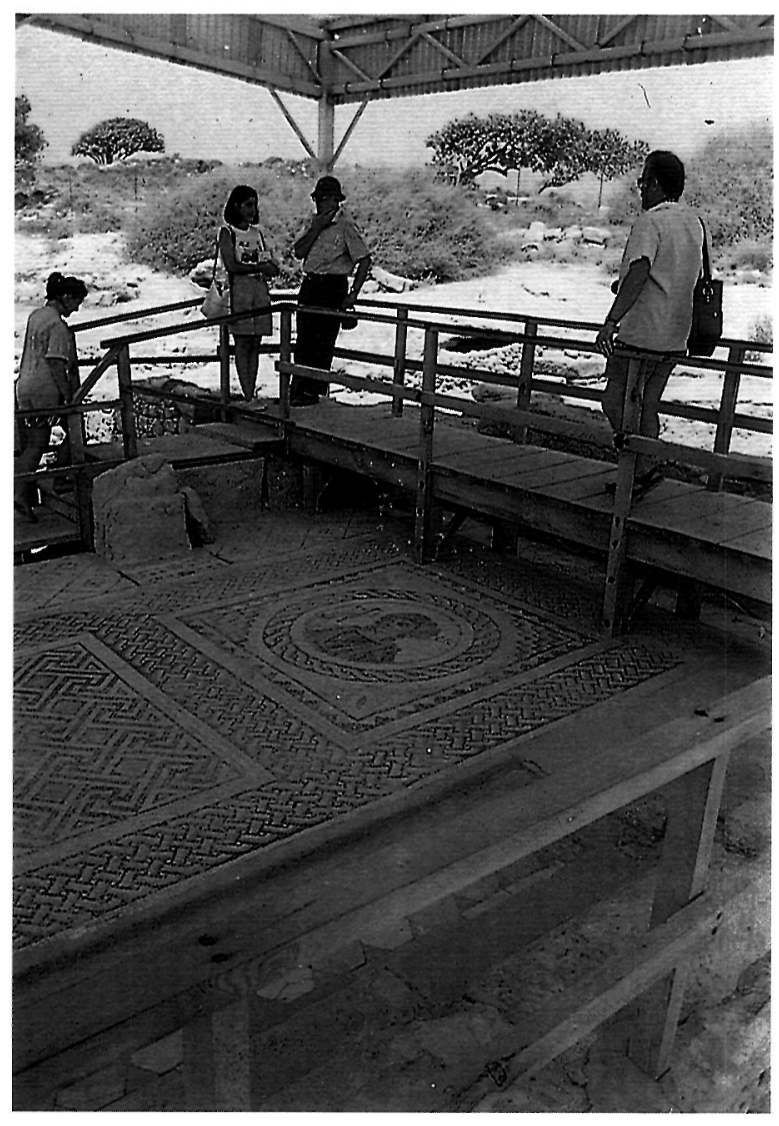

Fig.39.- Kourion.Casa de Eustolios. Frigidarium de las termas. Vista del mosaico de Ktisis.

forma magistral la representación de los sentimientos anímicos. En contraste, la ejecución de la mano derecha es torpe y el perfil está totalmente deformado. Se fecha en el siglo V.

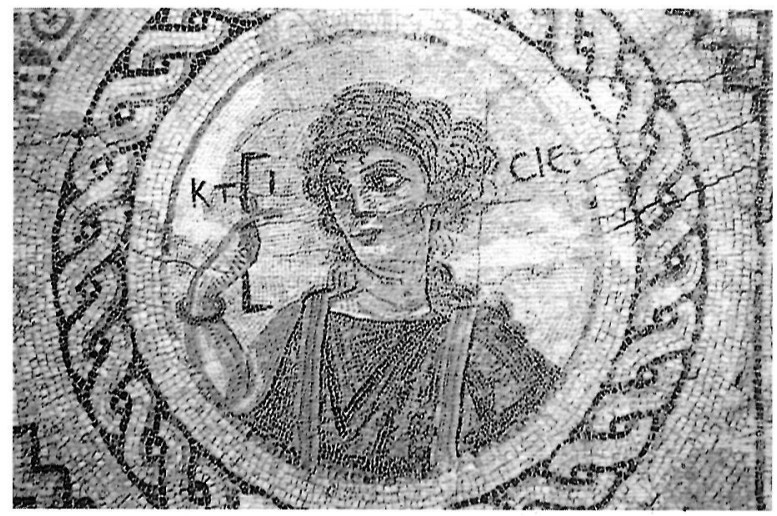

Fig.40.- Kourion. Casa de Eustolios. Ktisis 
Este cuadro responde a una costumbre muy generalizada entre los mosaistas del Bajo Imperio de representar abstracciones o personificaciones (Megalops y Chios, Phronesis, Thalata, etc.), e incluso figuras mitológicas, como los bustos de Tetis de Philippopolis, fechado en el segundo cuarto del siglo IV; ó de Ge, procedente del triclinio de Apamea de Siria, datado en el tercer cuarto del siglo IV, que ofrece cierto parecido con la figura de Ktisis en la boca y parte inferior del rostro. Tres alegorías, Euteknia, Dikaiosyne y Philosophia, decoran asimismo un mosaico de Philippopolis, de la primera mitad del siglo IV, expresando, como muy bien indicó J. Balty, un ideal pagano de vida en la Siria del siglo IV, la fidelidad de cierta élite social a los valores del helenismo. La personificación de Ktisis es bien conocida en mosaicos de Antioquía, entre los siglos IV y VI, con el significado de fundación, de posesión, de poder o de renovación. Así se la encuentra probablemente en la Casa del triunfo de Dionysos, Casa de Ge y de las estaciones, Casa de la diosa marina, Casa de Ktisis. Krisis, como alegoría del juicio, se la encuentra en otro mosaico sirio de Apamea, que J. Balty interpreta como una versión oriental del mito de Casiopea, fechado en el tercer cuarto del siglo IV. En los mosaicos hispanos también se representan ideas abstractas mediante bustos femeninos, como el medallón con la Abundancia de la villa soriana de Los Quintanares, lo que indica que aún en época tardía existía una unidad en todo el Imperio Romano y que los mismos conceptos y modas se extendían por todas las regiones.

La Casa de Eustolios conserva in situ otros mosaicos que el visitante puede contemplar recorriendo una pasarela de madera construida bajo una techumbre.

\section{Medallón con pato (fig. 41)}

En el hall de un edificio público de Kourion (ninfeo), situado en el sector noroeste de la ciudad, flanqueado por tres habitaciones pavimentadas con mosaicos geométricos en blanco y negro y un vestíbulo decorado con un pavimento de opus sectile, se encuentra un mosaico con un pato en el centro de una corona floral. Un paralelo exacto se repite en el mosaico de las estaciones de la Casa de los Caballos de Cartago, fechado entre los años 320-330. Medallones con prótomos de animales se encuentran en mosaicos de la misma fecha en Piazza Armerina, en Sicilia. El edificio parece que puede fecharse a finales del siglo III, pero el estilo de los mosaicos del hall apunta a una fecha posterior, concretamente los temas geométricos parecen de los siglos V y VI.

\section{La toilette de Venus (fig. 42)}

En las termas de Alassa se descubrió un mosaico que representa a Venus desnuda, de frente, sujetándose con ambas

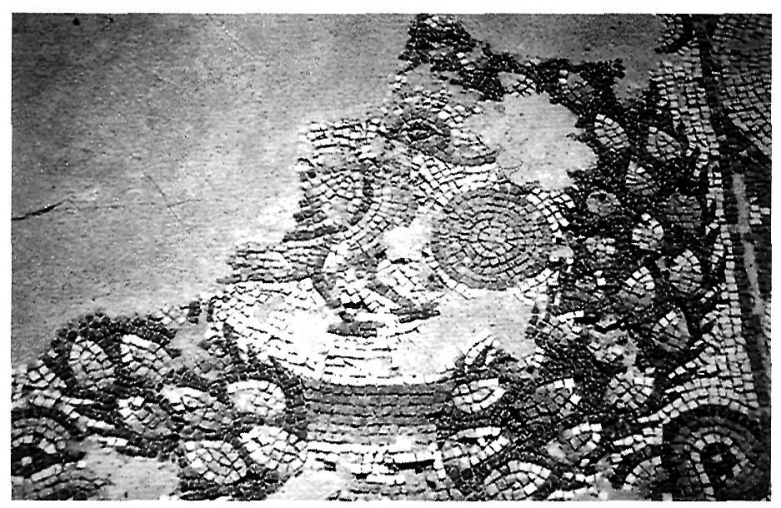

Fig. 41.- Kourion.Ninfeo.Medallón con pato

manos los cabellos. En el lado derecho se encuentra Eros, desnudo y con manto a la espalda, sosteniendo en su mano derecha un espejo y un joyero en la izquierda. Al otro lado de la diosa se ha representado un altar y sobre él un jarro. En la parte superior se lee una inscripción de saludo. Esta imagen de Venus, de ejecución un tanto torpe, fechada en el siglo V, tiene un paralelo notable en un mosaico de Thysdrus, datado entre los anos 280-300, con Venus Anadyomene saliendo del mar, flanqueada por erotes que le ofrecen un espejo y cintas. También presenta un cierto parentesco con la figura de Casiopea del mosaico de Palmira, que aparece igualmente colocada en posición frontal. El mosaico de Alassa se conserva actualmente en el Museo Arqueológico de Limassol.

La toilette de Venus es un tema frecuente en los mosaicos africanos. Se la encuentra en Cartago, en el mosaico de las estaciones de la Casa de los Caballos, también servida por Eros y por una dama; en los mosaicos con el triunfo de Venus

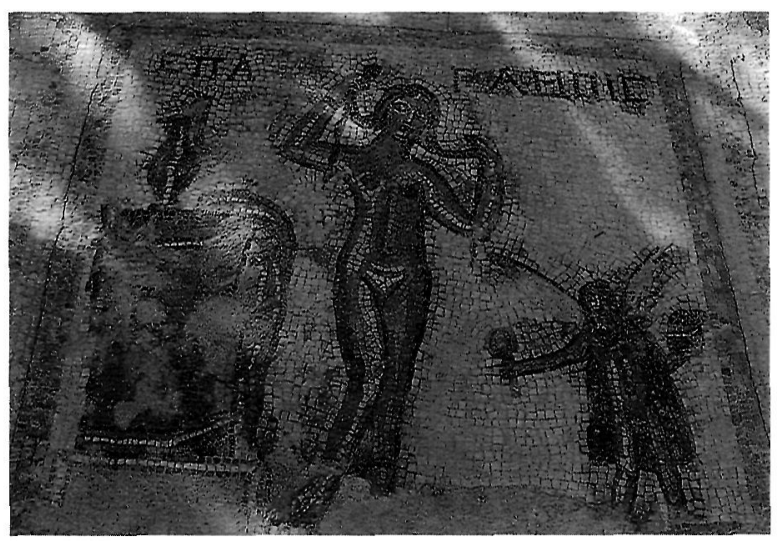

Fig. 42.- Museo de Limassol. Mosaico de las termas de Alassa con la toilette de Venus 
de Cartago, de finales del siglo IV o de comienzos del V; de Djemila, Casa del Asno, de la misma fecha, con Venus mirándose en un espejo; y de Setif, con el mismo tema y fecha que los anteriores, en donde un erote le presenta el espejo. En estos tres últimos pavimentos Venus se sienta en una concha sostenida por monstruos marinos, al igual que en un cuarto procedente de Philippopolis, con Venus también mirándose en el espejo, fechado en la mitad del siglo III.

En el mosaico chipriota llama la atención la desnudez de Venus en una zona fuertemente cristianizada en esas fechas. Sin embargo, esta representación no constituye una excepción ya que en el arte copto de un Egipto muy cristianizado, los temas mitológicos y el desnudo se representaban continuamente, como la figura en piedra de Dionysos desnudo de Sheikh Abado, del siglo IV; o el baño de Afrodita en un tapiz del siglo VI, conservado en el Museo del Louvre, en donde la diosa aparece desnuda al igual que sus cuatro acompañantes; o las dos nereidas en piedra halladas en Almas, de los siglos IV-V, etc.

\section{Figura dionisiaca (fig. 43)}

El Museo Arqueológico de Nicosia guarda un fragmento de mosaico figurado procedente de Lambousa. Representa a un joven desnudo, con manto sobre los hombros, que levanta con su mano izquierda un gran cuenco de cristal lleno de uvas, en actitud de ofrecimiento hacia una figura de la que sólo se conservan restos del ropaje de color rojo. La cabeza del joven, que recuerda muy de cerca a las de Aquiles de Kourión y Teseo de Nea Paphos, con las que también se asemeja en la posición levantada del brazo izquierdo, va coronada enteramente de flores. Evidentemente se trata de una figura del cortejo báquico con un paralelo muy claro en el panel del triunfo de Dionysos de la Casa de Aión, en Nea Paphos, datado en el siglo IV, en donde un joven desnudo ofrece al dios una fuente llena de frutos. En los sarcófagos dionisiacos, recogidos por T. Matz, aparecen con frecuencia figuras llevando bandejas o cestos llenos de frutos. Baste recordar el sarcófago de Baltimore con una ménade de espaldas que lleva una fuente con frutos: el de Princeton, en donde otra ménade, esta vez de rodillas, ofrece a la pareja divina, que aparece desnuda y sentada, una bandeja llena de frutos, etc. El tema de los erotes con canastillos llenos de frutos, fundamentalmente uvas con pámpanos, representado en los sarcófagos dionisiacos de época de la anarquía militar, como los del Louvre, Roma, Jerusalén, etc., es muy frecuente también en mosaicos báquicos.

A falta de otros datos que permitan fecharlo, los paralelos estilísticos dan a este mosaico una cronología en la primera mitad del siglo IV.

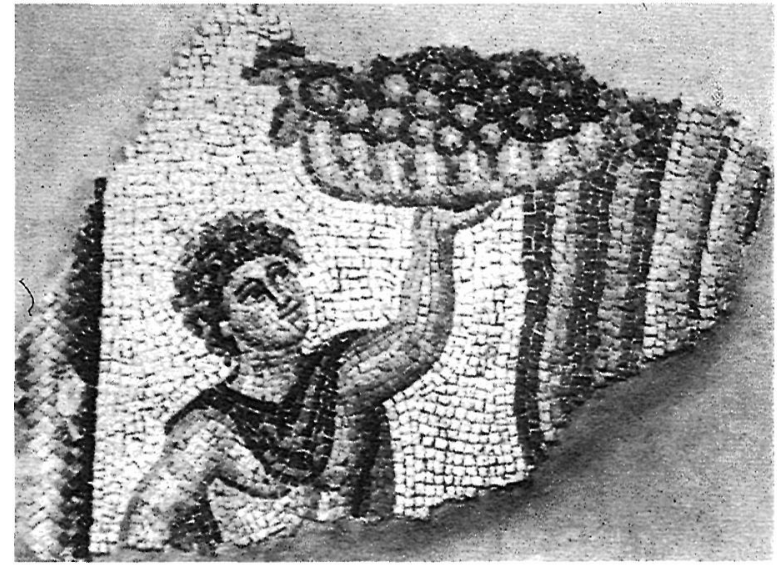

Fig. 43.- Museo de Nicosia. Mosaico de Lambousa con figura dionisiaca.

\section{Perro cazador (fig. 44)}

Procedentes de dos pequeñas habitaciones de las termas de Mansoura, se conservan en el Museo Arqueológico de Nicosia dos pavimentos con inscripciones griegas. Uno de los paneles, de forma cuadrada, representa una escena de caza en la que un perro acaba de atrapar a una perdiz; sobre él un letrero dice: «Buena caza»; debajo hay un objeto blanco no identificable. El perro está visto de perfil, con la cabeza vuelta hacia el lado izquierdo y la expresión de quien espera recibir órdenes. Se fecha en el siglo IV.

Este tipo de mosaicos con escenas de caza en las que sólo intervienen animales, arranca del final de la época helenística y tuvo mucha aceptación en Pompeya. Baste recordar el pavimento de la Casa del Fauno en donde se representa un gato con una perdiz; otro con perro atado con una cadena y la inscripción: «Cuídate del perro», etc. El tema de la caza de perdices está frecuentemente representado en mosaicos, como en la Casa de los Laberii, en Oudna, en donde un hombre disfrazado de perro se dispone a cazar tres perdices; o en el mosaico hispano de la villa romana de Málaga, con la leyenda de Bellerofonte y la Quimera acompañada de una escena de cacería, en la que intervienen un cazador y dos perros persiguiendo a dos liebres y a una perdiz. La cacería de liebres y perdices están ampliamente documentadas en mosaicos del Bajo Imperio.

\section{Mosaico circular (fig. 45)}

En el jardín del Museo Arqueológico de Larnaca se conserva un pavimento, de forma circular, procedente de las termas de Kition que se data a fines del período helenístico y 


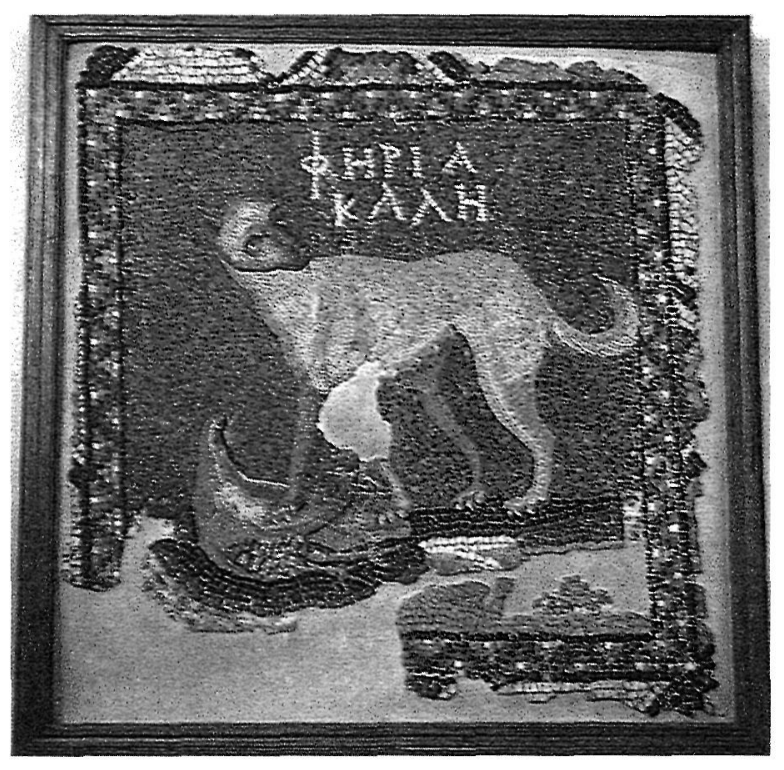

Fig. 44.- Museo de Nicosis. Mosaico de las termas de Mansoura con perro cazador.

comienzos de época romana. El mosaico, realizado en blanco y negro, va enmarcado por una línea de postas y otra de triángulos adyacentes escalonados. El centro se decora con una corona de hojas de acanto unidas por las volutas, que encierra una guirnalda de hojas de laurel rodeando un círculo formado por triángulos cuyos vértices rodean el motivo principal, hoy perdido. Seguramente se trataba de una cabeza de Medusa, de Helios o de Dionysos, a juzgar por otros mosaicos similares, como el hispano de la villa malagueña de Marbella, con cabeza de Medusa dentro de un círculo decorado también con hojas de acanto. Coronas de laurel y de hojas de acanto son frecuentes en mosaicos del siglo II de la villa hadrianea de Tívoli. El pavimento de Kition se fecha en el siglo II.

Es probable que el motivo central, de carácter mitológico, fuera destruido intencionadamente en época cristiana, como apunta C. Duliere refiriéndose a mosaicos de Siria y nosotros mismos hemos comprobado en algunos pavimentos hispanos preferentemente de tema báquico. En Chipre, el mosaico figurado de tipo mitológico desaparece en el siglo V, debido tal vez a la fuerte corriente iconoclasta de la iglesia paleocristiana, cuyo máximo exponente, Epifanio de Salamina era ya contrario a la representación de imágenes a finales del siglo IV. A partir de esas fechas quedan sólo los mosaicos geométricos, cuyo uso se generaliza en las iglesias paleocristianas. El hecho de que el mosaico de Kition provenga del lugar donde se levantó la Chrysopolitissa, hacen muy posible la hipótesis anotada. En Hispania el mosaico

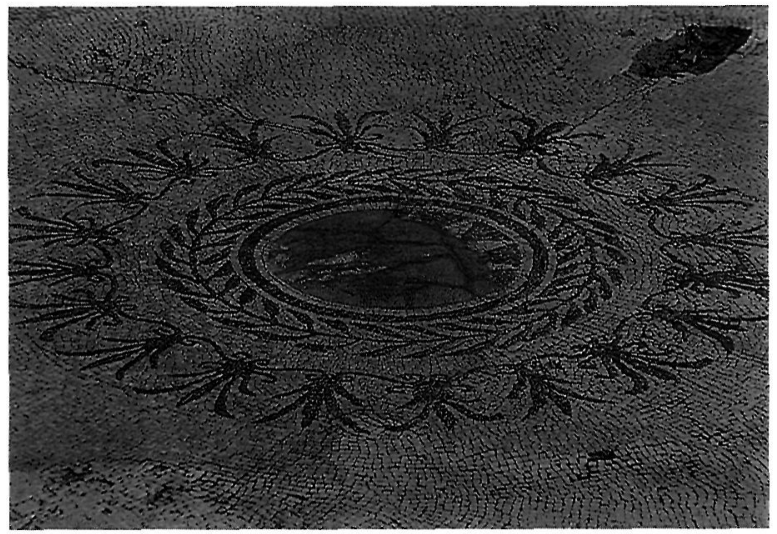

Fig. 45.- Museo de Larnaca. Mosaico de las termas de Kition.

figurado desaparece prácticamente también en el siglo V con la llegada de alanos, vándalos y suevos en 409-412.

\section{Mosaicos geométricos}

Los pavimentos de diversos edificios de Chipre iban decorados con diferentes mosaicos de temas geométricos, formando dibujos y combinaciones muy variadas que responden, en líneas generales, a modas de la musivaria del Bajo Imperio en las provincias orientales. Nuestro reciente viaje a la isla nos ha permitido conocer un excelente repertorio de mosaicos geométricos, la mayoría procedentes de basílicas paleocristianas y otros que pertenecen a edificios civiles. Examinaremos solamente unos cuantos que creemos más significativos.

En Chipre se conocen unas 56 basílicas fechadas entre los siglos IV y VII, muchas con suelos decorados con mosaicos. El cristianismo fue introducido en la isla por Pablo y Bernabé $\mathrm{y}$, aunque durante el Bajo Imperio Chipre fue azotada por enconadas disputas teológicas, en general la isla gozó en estos siglos de un gran período de paz y tranquilidad. Algunas de las principales figuras del cristianismo del Bajo Imperio eran oriundas de Chipre, como el citado Epifanio de Salamina, gran conocedor de las herejías cristianas del siglo IV; Hilarión de Gaza, fundador del monacato palestino, practicó su ascesis en la isla. En el Concilio de Nicea, celebrado en el año 325, participaron tres obispos de Chipre; y en el de Sardes, que tuvo lugar unos veinte años después, estuvieron presentes doce obispos chipriotas.

En el siglo $\mathrm{V}$ la persistencia del paganismo en la isla era aún fuerte, como lo indican algunos mosaicos de la Casa de Teseo en Nea Paphos. Por ejemplo, el mosaico del baño de Aquiles niño es de inspiración y de carácter esencialmente pagano, según afirman W.A. Daszewski y D. Michaelides. En este sentido es muy interesante el mosaico con aves y peces 
de la Casa de Eustolios en Kourion, en donde una inscripción alude a los símbolos de Cristo, mientras otras celebran que la vuelta del bienhechor Eustolios a su ciudad natal, recuerda la visita de su anterior patrono, Apolo. Los mosaicos de este edificio son un claro exponente de la ambivalencia cristianapagana muy típica del momento.

\section{Mosaicos de la Casa de Gladiadores en Kourion}

Además de los pavimentos policromos con escenas de combates de gladiadores, esta casa, que comprende también unas termas, ha proporcionado dos bellos mosaicos bícromos decorados con temas geométricos. Uno de ellos (fig. 46) presenta una gran estrella de ocho puntas dentro de un círculo que, a su vez se inscribe en un cuadrado. En los espacios que hay entre los rombos se han colocado peltas. El esquema de la estrella de rombos es una de las composiciones geométricas más difundidas en la musivaria romana. Se documenta ya en Pompeya a partir de la mitad del siglo I, así como en la villa hadrianea de Tívoli y en Ostia, siendo muy frecuente en mosaicos de Hispania, Galia y Britania, fechados en el siglo II. La misma composición se documenta en pavimentos de Antioquía, en la Casa de Dionysos y Ariadna o en la del Barco de Psyque; en Olimpia, con unas fechas en los siglos II-III; y en Cilicia, en mosaicos de época severiana y postseveriana. El esquema perdura en el Bajo Imperio y así lo encontramos en varios mosaicos hispanos de esta época, como Cuevas de Soria, Rielves (Toledo), Liédena (Navarra), etc.

El otro pavimento (fig. 47) ofrece una composición geométrica formada por rombos, triángulos y cuadrados adyacentes que van dibujando distintas figuras, como estrellas de cuatro rombos con cruces en su interior, o grupos de cuatro triángulos con los vértices hacia afuera y cuadrado central decorado con damero. Este último esquema, Ilamado «scalloped squares» es muy frecuente en Chipre, baste citar el mosaico de la perdiz (fig. 48) de la sala central de los baños de la Casa de Eustolios, en la misma localidad de Kourion, fechado a comienzos del siglo V; o el pavimento de la nave de la basílica de Agia Trias, en Yialousa, de la misma época, tan similares ambos que D. Michaelides duda en creerlos obras de un mismo taller. El mismo dibujo se repite en África, en el mosaico de Licurgo de la villa romana de Silin, obra del siglo IV.

\section{Mosaicos de la Casa de Eustolios en Kourion}

Uno de los mosaicos geométricos de la Casa de Eustolios ofrece una decoración formada por cuatro losanges cuyos extremos terminan en cuartos de círculo ornado con tres hojas (fig. 49). Los losanges van entrelazados por un cable de dos cabos que forma un rombo central con rosetón en su interior y triángulos laterales decorados con líneas dentadas superpuestas. Este esquema compositivo es particularmente frecuente

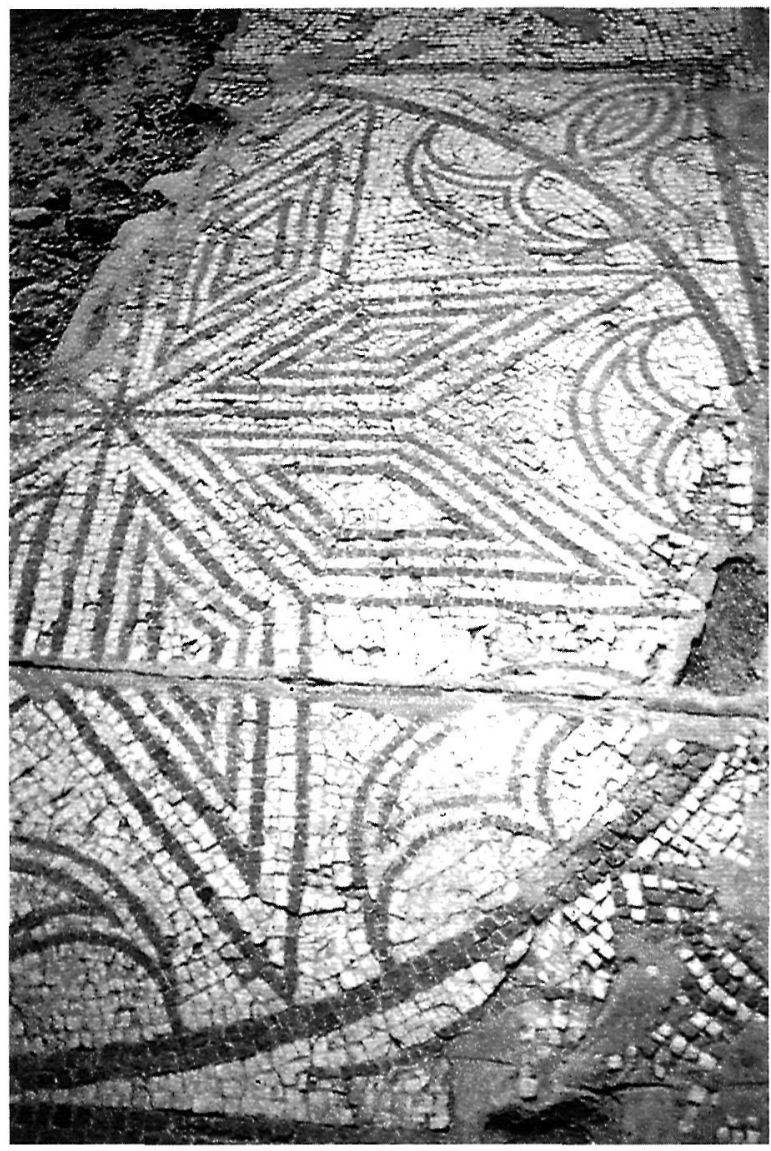

Fig. 46.- Kourion. Casa de los Gladiadores. Mosaico geométrico.

en los mosaicos del Bajo Imperio en Oriente. Bordean esta composición filas de flores cuatripétalas, que van formando círculos, cuyo interior se decora con nudos de Salomón inscritos en rombos.

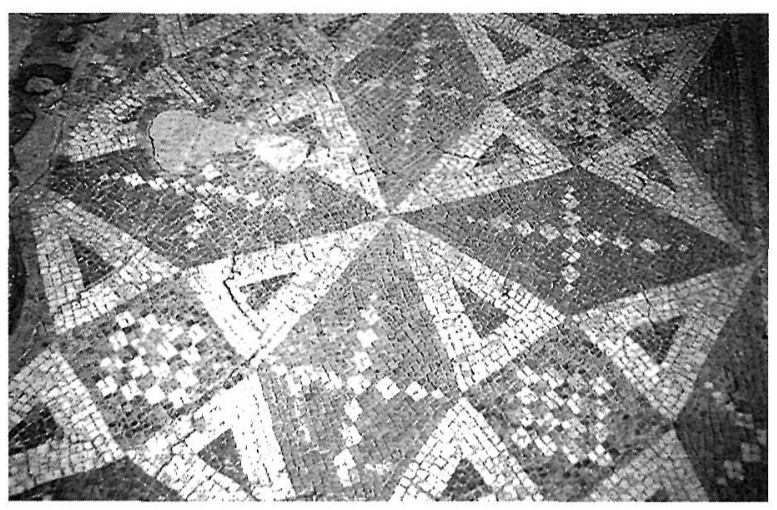

Fig. 47.- Kourion. Casa de los Gladiadores. Mosaico geométrico. 


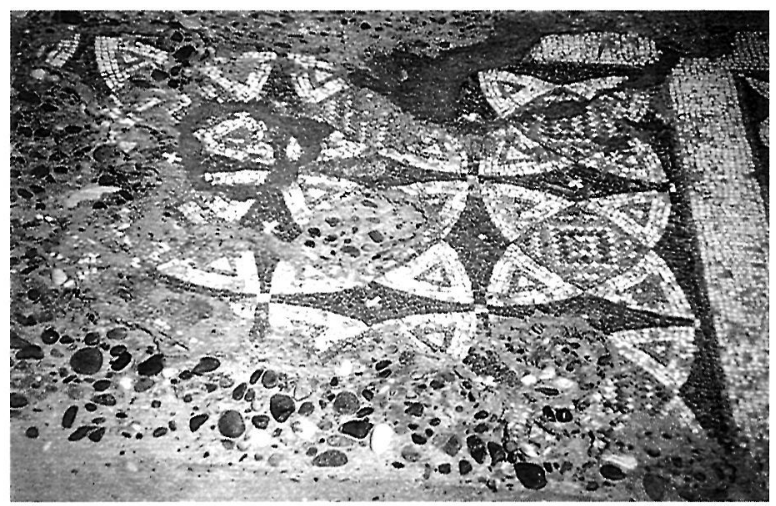

Fig. 48.- Kourion. Casa de Eustolios. Detalle del mosaico de la perdiz.

El vestíbulo de entrada de esta misma casa ofrece otro mosaico geométrico decorado con ocho cuadrados, que forman un octógono central, en cuyo interior se inscribe una corona multicolor que encierra una inscripción de bienvenida para el visitante (fig. 50). Los cuadrados van decorados con nudos de Salomón, alternando con triángulos tangentes por su vértice y series de rombos superpuestos. Este esquema decorativo está bien documentado en el Oriente, baste recordar la sinagoga de Apamea de Siria, de 391-392; la nave de Deir Charqi, de la misma fecha; las Casas de Ge y de las Estaciones de Antioquía, etc.

\section{Mosaicos de la basílica paleocristiana de Kourion}

Se trata de un gran edificio de tres naves y un solo ábside, cuyos suelos van decorados con excelentes mosaicos de tema geométrico, algunos de los cuales examinaremos brevemente.

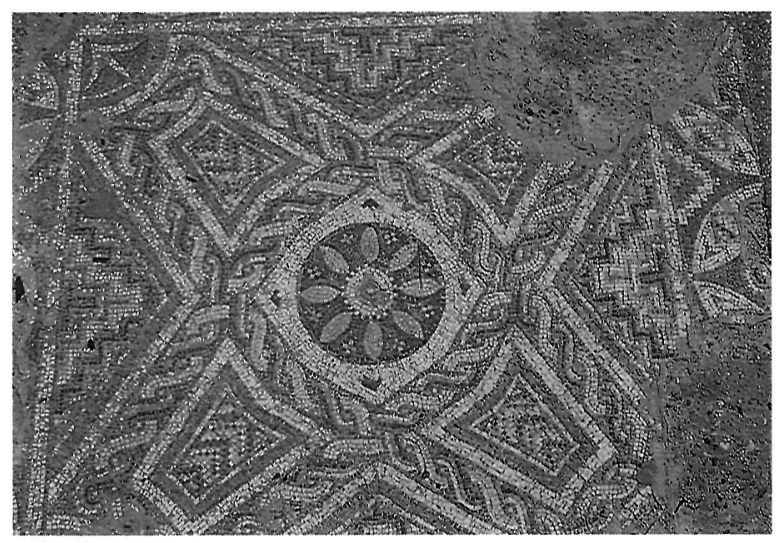

Fig. 49.- Kourion. Casa de Eustolios. Mosaico geométrico.

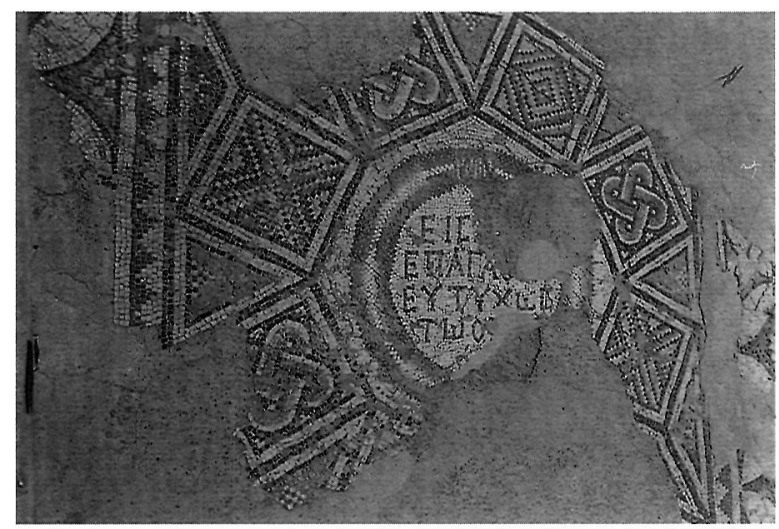

Fig. 50.- Kourion. Casa de Eustolios. Mosaico geométrico.

Los temas decorativos son muy corrientes y se documentan también en pavimentos del Mediterráneo occidental, lo que prueba la existencia de una unidad temática a lo largo de todo el Imperio, siendo su nota más destacada la elegancia de la sencillez. En el colorido predomina el blanco y el negro; algunos dibujos se habían repetido en mosaicos durante muchos siglos, antes de que fueran copiados en la basílica de Kourion, y esto demuestra la pervivencia de ciertos temas.

Uno de los pavimentos de la nave derecha va decorado con una red de rombos que inscriben otros, de menor tamaño, en su interior (Fig. 51). Este esquema decorativo, a base de hileras de rombos encerrando una diminuta figura geométrica, es muy frecuente en la decoración musivaria. En Hispania se documenta en mosaicos de las villas de Los Quintanares y Uxama (Soria) y de Albesa (Lérida), todas del Bajo Imperio; y más cerca de Chipre en el pavimento de Eros y Psique de Byblos, fechado a finales del siglo II o comienzos del siguiente; es también muy usado en los pavimentos de Antioquía: Casas de Ifigenia, de época hadrianea o antoniniana; de Oceano y Tetis del siglo III; de Menandro, del período hadrianeo; del Barco de Psique, del siglo III. Esta composición geométrica es igualmente frecuente en mosaicos africanos y de Italia. Su cronología va del siglo II al V.

La decoración geométrica de otros suelos es más complicada y variada, alternando con otras más sencillas (Fig 52). A veces el dibujo lo forman hexágonos secantes con cuadrados inscritos en el interior, tema muy frecuente en los mosaicos hispanos del Bajo Imperio, como en uno de Rielves (Toledo). Junto a este esquema aparece otro con complicadas figuras geométricas, y un tercero que va decorado con estrellas de cuatro puritas con rombos inscritos en el centro, y entre ellas círculos que encierran rombos de lados curvos. Una última composición forma distintas figuras geométricas con peltas en los ángulos y cruz gamada en el interior del octógono central. 


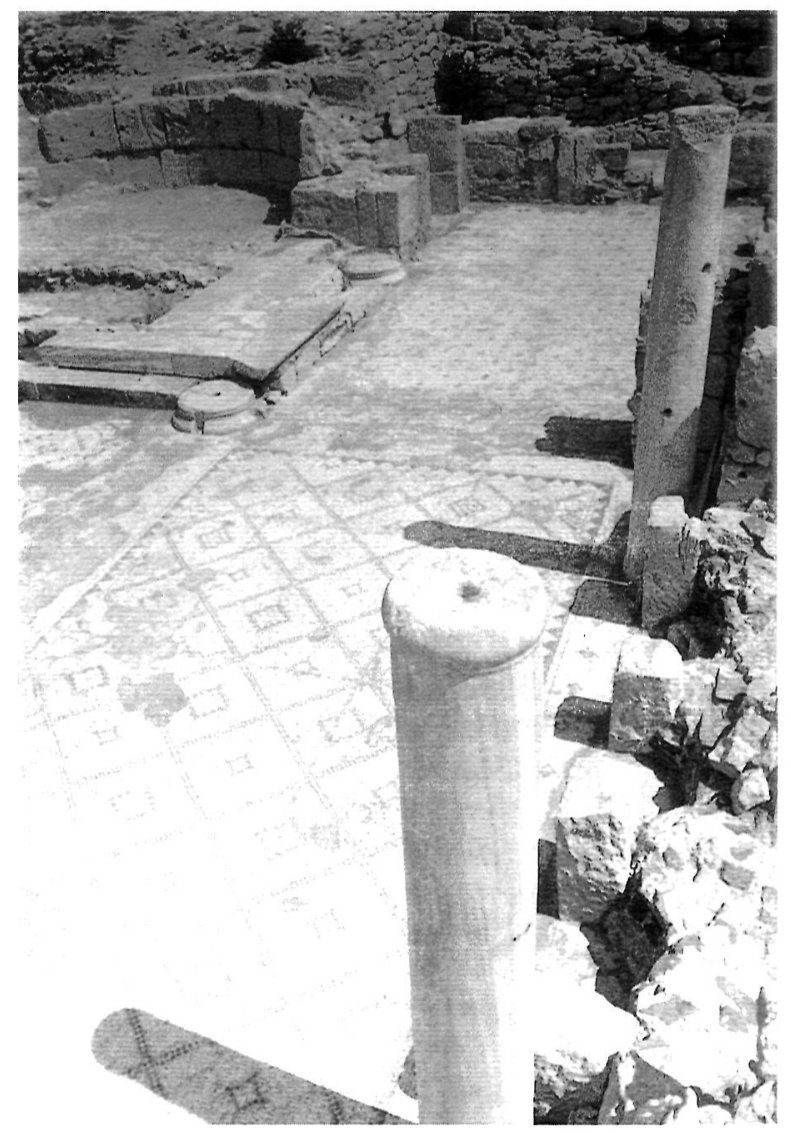

Fig. 51.- Kourion. Basílica paleocristiana. Mosaico geométrico

Estos cuatro esquemas decorativos se alternan a lo largo de esta nave de la basílica.

$\mathrm{Al}$ oeste de la iglesia se encuentra el baptisterio, que tiene forma de pequeña basílica de tres naves precedida de un narthex. La decoración de uno de los pavimentos (fig. 53) es muy sencilla: tres hileras de dobles círculos y elipses, con cruces de Malta y motivos decorativos en su interior, que se entrelazan alternativamente. En la fila del centro alternan elipses y cuadrados decorados con cuatro círculos, que resultan de la intersección de flores cuatripétalas blancas, con rombos de lados curvos en su interior, o con cuatro triángulos curvilíneos entrelazados formando aspas. El pavimento se fecha en el siglo VI.

Los paralelos para este esquema decorativo se encuentran en mosaicos del Líbano: coro de la iglesia de Zahrani, en donde los cuadrados van decorados con cruces y con el alfa y la omega; mosaico de Leontius en la villa Awzasi, fechado entre la segunda mitad del siglo V y la primera del VI; iglesia de Ghiné, en pavimentos de la entrada y de la nave, fechados a fines del siglo $\mathrm{V}$ o comienzos del siguiente. En estos dos últimos mosaicos los círculos y las elipses van decorados con

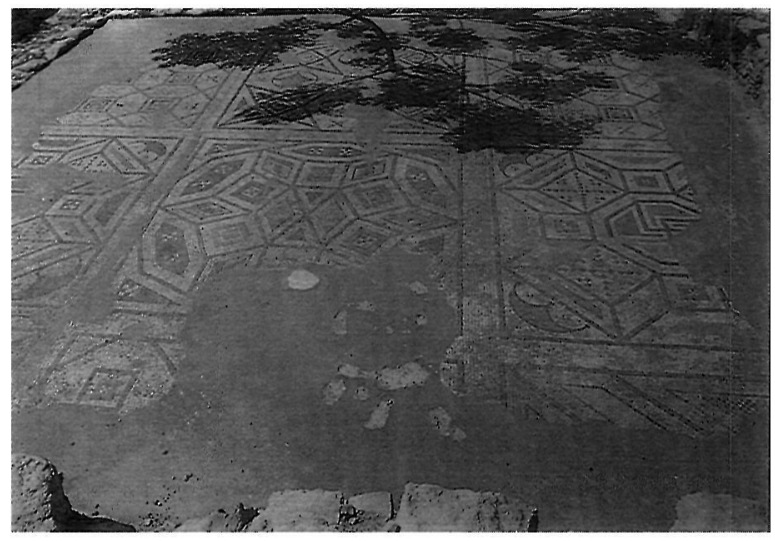

Fig. 52.- Kourion. Basílica paleocristiana. Mosaico geométrico

animales. La misma decoración, un tanto barroca y recargada, se repite en la villa de Janah, con palmeras y pájaros en los cuadros. El dibujo se encuentra idéntico en un edificio cristiano de Atenas de la segunda mitad del siglo V, documentándose un esquema muy parecido en la basílica Chrysopolitissa de Paphos, pero aquí los cuadrados han sido sustituidos por rombos. Este esquema decorativo geométrico reaparece igualmente en mosaicos de Antioquía: Casa de Aión, con cruces de Malta en el interior de los círculos y figuras geométricas en los cuadrados; Casa de los prótomos de rebecos; y en DH 27 $\mathrm{H}$. El dibujo sólo con círculos es frecuente en mosaicos del Oriente, baste recordar los pavimentos de la Casa de la diosa marina y del Fenix en Antioquía; y en el Líbano, baptisterio de Zahrani e iglesia de Ghiné. Igualmente se repite en pavimentos de Grecia: basílica de Hermione, de comienzos del siglo VI; habitación VI de la basílica Alfa en Nikópolis, del segundo cuarto del siglo VI; habitación II de la basílica Beta, en la

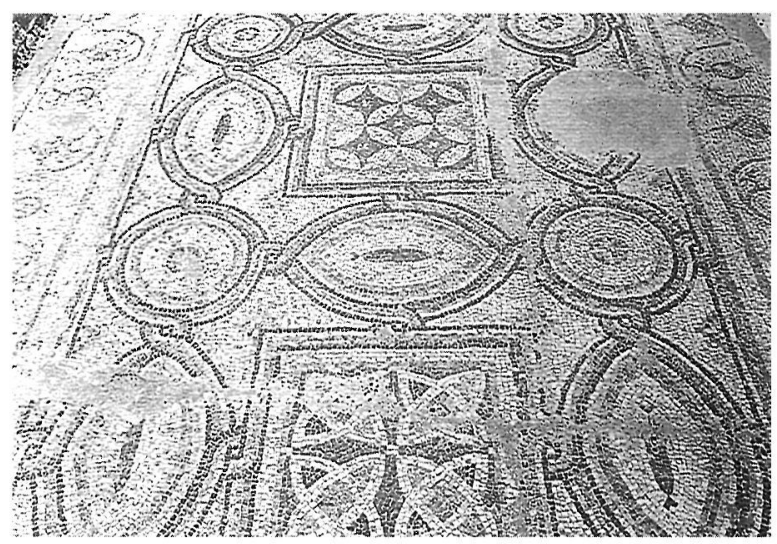

Fig. 53.- Kourion. Basílica paleocristiana. Mosaico del baptisterio. 
misma localidad, de finales del siglo V. En otros pavimentos de Nikópolis, de la misma habitación y edificio, los círculos con cruces de Malta en el interior alternan con cuadrados, 10 que aproxima el esquema de este dibujo al del pavimento chipriota. Este diseño, muy barroco en la ejecución, se encuentra también en Chipre en la iglesia bajo la basílica de Soloi, del siglo V-VI; y en la nave y el baptisterio de la basílica A de Agios Georgios. Puntualizan W.A. Daszewski y D. Michaelides, al estudiar estos mosaicos, que el dibujo era ya usado en Chipre en el siglo III, como se comprueba en la Casa de Dionysos. Este esquema decorativo se repite igualmente en Cesarea Marítima en mosaicos de los siglos VI-VII.

Señalan los autores citados que «la homogeneidad del repertorio y estilo entre los mosaicos de las diferentes partes de la isla, especialmente en los siglos V y VI, no permite dudar de que los mosaístas pertenecen a un ambiente artístico uniforme, de bien definidas tradiciones y predilecciones». De la comparación entre los diferentes mosaicos de Chipre, concluyen W.A. Daszewski y D. Michaelides que los talleres de los musivarios trabajaban en estrecho contacto unos con otros, o que un mismo taller trabajaba en los edificios civiles y religiosos al mismo tiempo en estas localidades, y que los musivarios frecuentemente demostraban características locales aunque estaban influenciados por corrientes artísticas de fuera de la isla. Este influjo venía no de Grecia o de Asia Menor, sino del Este. Los paralelos llevan en primer lugar a Antioquía, pero también a Siria, Jordania, Líbano y Palestina. Probablemente todas estas regiones formaban una única unidad artística, al igual que muchos mosaicos de Sicilia, en el Bajo Imperio, y de Hispania se vinculan con los del África Proconsular, integrándose todos ellos dentro de una misma corriente cultural. Al estudiar los mosaicos de Sicilia, R.J.A. Wilson se plantea tres cuestiones sin llegar a decidirse por ninguna solución clara en cada caso: los artesanos sicilianos usaban «copy-books», o musivarios africanos trabajaban en Sicilia, o los mosaicos llegaban ya confeccionados. Nosotros deducimos del estudio de algunos mosaicos hispanos, comparándolos con otros africanos o de influjo africano, que aunque algunos pavimentos pudieron ser hechos por musivarios africanos, lo corriente era que los artesanos hispanos usaran cartones de donde copiaban libremente los grupos o las figuras, sin preocuparse de dar mucha unidad a la composición. Pensamos que algo parecido debía suceder en Chipre con respecto a Siria, Palestina o Líbano.

\section{Mosaicos de la basílica Chrysopolitissa de Paphos}

Los suelos de la basílica Chrysopolitissa de Paphos iban decorados con diferentes mosaicos geométricos. Se ha pensado que tendencias iconoclastas contra el uso de las imágenes en lugares religiosos, podían estar en la base de esta tendencia a las figuras geométricas. Sin embargo, la abundancia de dibujos geométricos en los pavimentos hispanos del Bajo Imperio indica que era una corriente decorativa de la época. Por ejemplo, los mosaicos con imbricaciones y flor en su interior (fig. 54) son numerosos en todas las épocas y particularmente abundantes en la musivaria de Antioquía durante el siglo VI. Los mosaistas realizaron dos versiones de este dibujo: el primero no lleva el perfil de las imbricaciones señalado por una línea de color, mientras que el segundo lo lleva reforzado. Al primer grupo pertenecen en Chipre varios mosaicos de la basílica de Kourion; del edificio público de la misma ciudad; y de la basílica Agia Trias en Yialousa. La segunda versión fue utilizada en pavimentos posteriores, estando documentada en mosaicos chipriotas del baptisterio de la basílica de Kourion; en la basílica A de Agios Georgios en Peyia; en el atrio del nivel superior de la basílica de Chrysopolitissa de Paphos; y en la basílica de Shyrvallos en Ktima-Paphos. Se empleó con frecuencia en pavimentos de Siria y de Palestina, siendo raro su uso en otras provincias del Imperio bizantino. W.A. Daszewski y D. Michaelides mencionan a este respecto los mosaicos de la basílica Heracleia; de la basílica D de Nikópolis; los mosaicos colocados en la pared de St. Demetrios y del Acheropoietos de Salónica. Se conocen, asimismo, algunos ejemplos en pavimentos de Cilicia. Chipre ha dado dos pavimentos procedentes de la iglesia de Soloi, uno de ellos se fecha en la segunda mitad del siglo IV, y el otro a finales del siglo V o comienzos del siguiente. A la primera decoración pertenecen varios mosaicos de Antioquía procedentes de la Casa del Fenix; del nivel superior de la Casa de Aión; de los Baños F; de la Casa del Buffet Supper; dos ejemplares de Arab Darasi; y de la iglesia de Machouba. En el Líbano se documenta en pavimentos, fechados en el siglo IV, de la iglesia de Zahrani; de Ain es-Samaké; y en los de la villa de Janah.

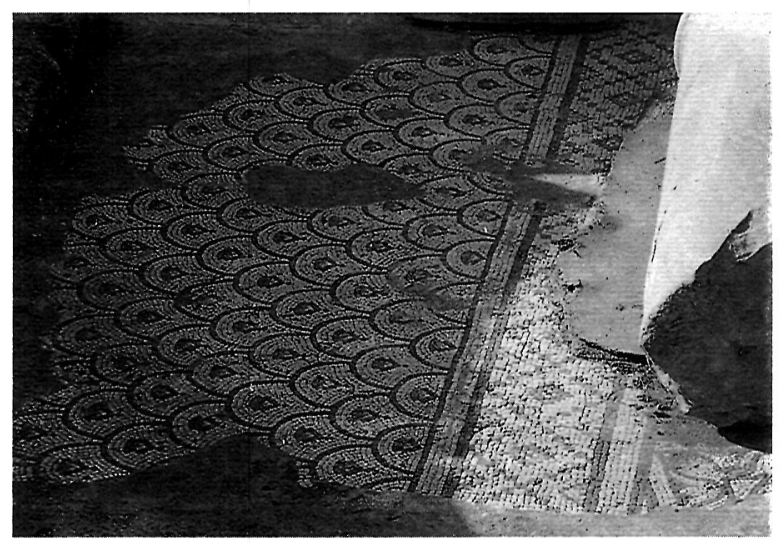

Fig. 54.- Paphos. Basílica Chrysopolitissa. Mosaico geométrico. 
Hay que añadir a lo escrito por W.A. Daszewski y D. Michaelides, que estas dos formas de dibujo con imbricaciones fueron frecuentemente empleadas, con variantes, por los musivarios hispanos del Bajo Imperio. Se encuentran en la mencionada villa soriana de Los Quintanares, con arco puntiagudo y hojas en el interior, idéntico a un pavimento de la Casa n. ${ }^{\circ} 10$ de Bulla Regia; en la villa de El Romeral en Lérida, con temas florales, aves y cestos en el interior; en la villa de Gárgoles-Cifuentes (Guadalajara); en Torre de Palma (Portugal); en Mérida; en Santervás del Burgo (Soria), etc. Los mosaicos hispanos se relacionan, sin embargo, más con sus congéneres africanos que con los del Oriente. Son un tanto recargados en la decoración del arco y del interior, careciendo de la sencillez de los orientales. Todo ello indica que los mismos temas reciben un tratamiento diferente en las distintas regiones del Imperio y que todavía en el Bajo Imperio no se había perdido la unidad artística del mundo romano. Hispania mantenía relaciones de todo tipo con las regiones del Oriente. D. Fernández Galiano ha señalado que una serie de mosaicos hispanos del Bajo Imperio: Fraga, Daragoleja, Baños de Valdearados, etc., siguen de cerca prototipos orientales. Se sabe, por otra parte, que artistas orientales, como orfebres, trabajaban en la Península Ibérica en tiempos de las invasiones bárbaras (409-412), haciendo joyas que seguían patrones orientales, según indican las piezas de Elche. También algunos sarcófagos, como los de Écija, Singilia Barba y Alcaudete, obedecen a prototipos orientales.

A esta misma conclusión se llega al examinar el esquema compositivo de círculos secantes que se encuentra en dos pavimentos de la basílica Chrysopolitissa de Paphos. Uno de ellos (fig. 55) ofrece filas de círculos secantes que forman «scalloped squares», tema documentado en la citada nave de la basílica de Agia Trias en Yialousa y en las termas de la Casa de Eustolios en Kourion. Este dibujo, que se empleó a partir del siglo V, es muy frecuente en pavimentos de Siria y de

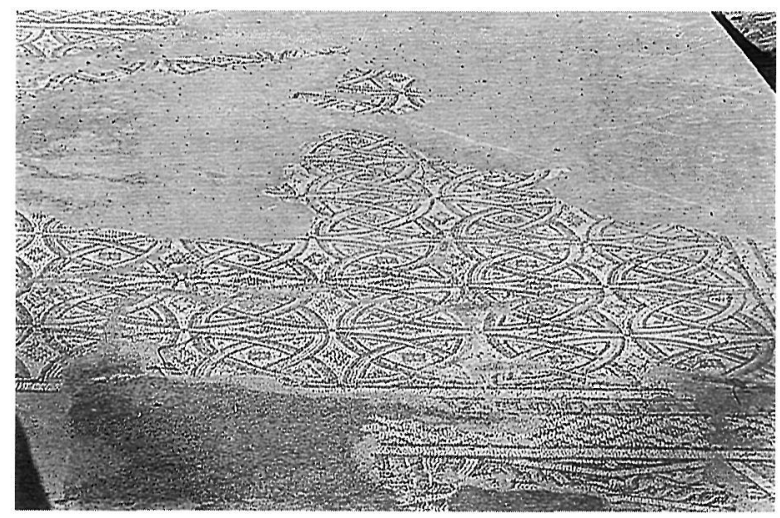

Fig. 55.- Paphos. Basílica Chrysopolitissa. Mosaico geométrico.

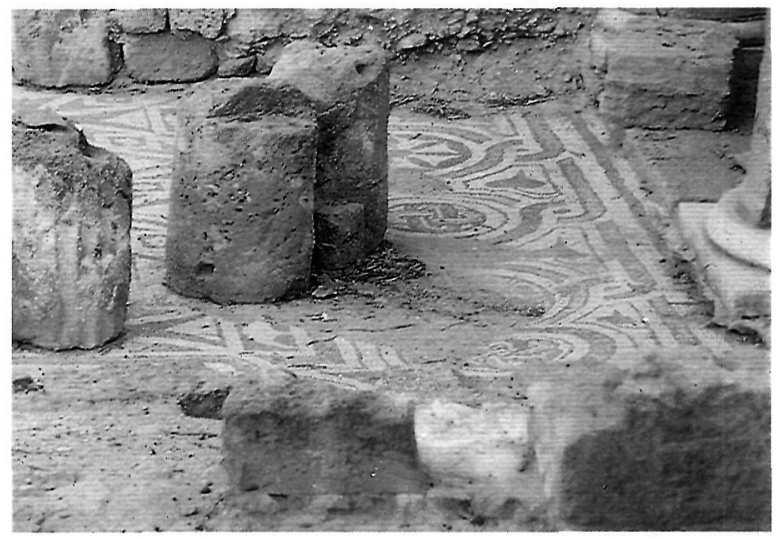

Fig. 56.- Paphos. Basílica Chrysopolitissa. Mosaico geométrico.

Palestina, e incluso en la basílica de St. Anastasios en Arkasa de los Cárpatos, en el Dodecaneso, siendo desconocido entre los mosaicos de Grecia. En Paphos aparece en el nivel superior de la basílica Chrysopolitissa. El otro pavimento (figs. 5657), también polícromo, pertenece a la estructura original del edificio, que se fecha en el siglo IV. Está bordeado por una franja de círculos entrelazados, decorados en su interior con diversos motivos, como rosetas de seis pétalos, nudos de Salomón, etc. El campo del mosaico ofrece un esquema decorativo de elipses entrecruzadas con cuadrados en su interior y otros más grandes en el centro de los círculos. La misma composición se documenta otras dos veces en mosaicos chipriotas de los siglos V y VI: en el diaconicon de la basílica de Kourion y en la nave A de Agios Georgios, en Peyia. El esquema se repite cien años más tarde en el ábside norte de la basílica de Agya Trias, en Yialousa. Dos mosaicos hispanos de la villa toledana de Rielves ofrecen el mismo dibujo de círculos secantes, que también se documenta en Baños de Valdearados,

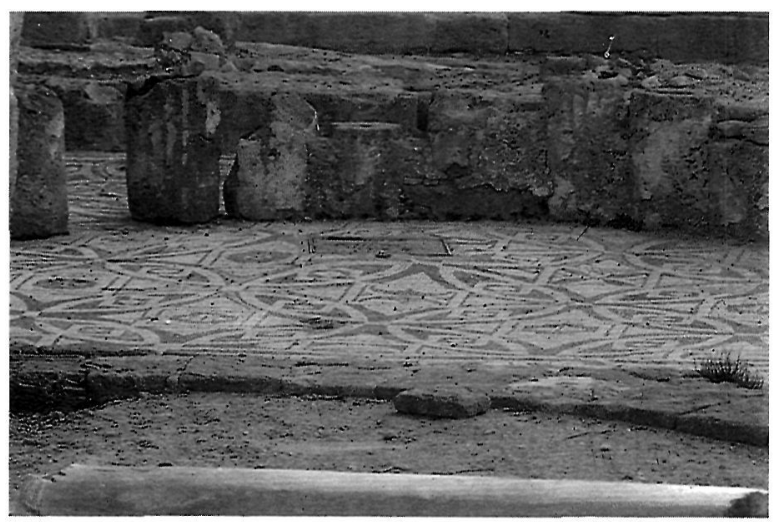

Fig. 57.- Paphos. Basílica Chrysopolitissa. Mosaico geométrico. 
todos de época tardoimperial, lo que indica que se trata de temas muy extendidos en todo el Imperio durante el Bajo Imperio.

En resumen, aconsejamos a todos los estudiosos de la musivaria romana que visiten Chipre para conocer sus excelentes mosaicos, dignos de ser visitados por su calidad, cantidad y buen estado de conservación.

\section{BIBLIOGRAFÍA}

ÁLVAREZ MARTíNEZ, J.M., 1990: Mosaicos romanos de Mérida. Nuevos hallazgos. Mérida.

BALTY, J., 1977: Mosaïques antiques de Syrie. Bruxelles.

- 1981: La Mosaíque Antique au Proche-Orient. I. Des origines à la Tétrarquie, ANRW 11, 12.2, $347 \mathrm{ss}$.

- 1989: La mosaïque en Syrie. La Syrie de l'époque achémenide à l'avénement de l'lslam. Archéologie et Historire de la Syrie II. Saarbrucken.

BALTY, J. Ch., 1981: Guide d'Apamée. Bruxelles.

BECATTI, G, 1961: Scavi de Ostia. IV. Mosaici e pavimenti marmorei, Roma.

BIANCHI-BANDINELLI, R., 1971: Roma. El fin del arte antiguo. Madrid.

BLAKE, M.E., 1936: Roman Mosaics of the second century in Italy, MAAR 13.67 ss.

BLANCO FREIJEIRO, A., 1952: Mosaicos antigus de asunto báquico. Madrid.

- 1978: Mosaicos romanos de Itálica. Madrid.

BLÁZQUEZ, J.M., 1980; Los mosaicos romanos de Torre de Palma. Monforte (Portugal), AEspA 53, $125 \mathrm{ss}$.

- 1981: Mosaicos romanos de Córdoba, Jaén y Málaga. Madrid.

- 1982: Mosaicos romanos de Sevilla, Granada, Cádiz, y Murcia. Madrid.

- 1982: Mosaicos romanos de la Real Academia de la Historia, Ciudad Real, Toledo, Madrid y Cuenca. Madrid.

- 1982: EI mosaico con el triunfo de Dioniso de la villa romana de Baños de Valdearados (Burgos), Hom. Sáenz de Buruaga. Madrid, $407 \mathrm{ss}$.

- 1985: Mosaicos romanos del Campo de Villavidel (León) y de Casariche (Sevilla), AEspA 58, $107 \mathrm{ss.}$

- 1986: Cosmogonía mitraica en un mosaico de Augusta Emerita, AEspA 59, 89 ss.

- 1989: Mosaicos del Museo Arqueológico de Estambul, Honen. al Prof. A. Blanco Freijeiro. Madrid, $353 \mathrm{ss}$

BLÁZQUEZ, J.M. - LÓPEZ MONTEAGUDO. G., 1990: Iconografía de la vida cotidiana: temas de caza, Alberto Balit in memoriam. Guadalajara, $59 \mathrm{ss}$.

BLÁZQUEZ J.M. - LÓPEZ MONTEAGUDO - NEIRA JIMÉNEZ, M.L. - SAN NICOLÁS PEDRAZ, 1986: La mitología en los mosaicos hispano-romanos, AEspA 59, 101 ss.

- 1986: Hallazgo de mosaicos romanos en Beas de Segura (Jaén), AEspA 59, 227 ss.

- 1989: Mosaicos romanos de Lérida y Albacete. Madrid.

- 1989: Mosaicos romanos del Museo Arqueológico Nacional. Madrid.

BLÁZQUEZ, J.M. - MEZQUIRIZ, M.A., 1985: Mosaicos romanos de Navarra. Madrid.
BLÁZQUEZ, J.M. - ORTEGO, T., 1983: Mosaicos romanos de Soria. Madrid.

BUDDE, L., 1969: Antike Mosaiken in Kilikien. 1. Relinghausen.

CAMPBELL, S., 1988: The Mosaics of Antioch. Toronto.

CANTO, A.M., 1976: El mosaico del nacimiento de Venus en Itálica, Habis 7, $293 \mathrm{ss}$.

CARANDINI, A. et alii. 1982: Filosofiana. La villa de Piazza Armerina. Palermo.

CHEHAB, M.H., 1959: Mosä̈ques du Liban. París.

DASZEWSKI, W.A., 1985: Dionysos der Erlöser. Mainz.

- 1988: Guide to the Paphos Mosaics. Cyprus.

DASZEWSKI, W.A. - MICHAELIDES, M., 1988: Mosaics Floors in Cyprus. Ravenna.

DONCEEL-VOUTTE, P., 1988: Les pavements des églises byzantines de Syrie et du Liban (Louvain-la-Neuve).

DULiÈrE, C., 1968: La mosaïque des Amazones. Fouïlles d'Apamée de Syrie. Bruxelles.

DUNBABIN, K.M.D., 1978: The Mosaics of Roman North Africa. Oxford.

FERNÁNDEZ-GALIANO, D., 1984: Complutum. II. Mosaicos. Madrid.

- 1987 Mosaicos romanos del Convento Cesaraugustano. Madrid.

- 1989: La villa de Materno. Mosaicos romanos in memoriam $M$. Fernández-Galiano. Madrid, 255 ss

FOUCHER, L., 1975: Le char de Dionysos, CMGR II, $55 \mathrm{ss}$

GARCÍA-GELABERT, M.P.-BLÁZQUEZ, J.M, 1989: Consideraciones en torno a los mosaicos de cantos roda dos de Cástulo (Jaén), Mosaicos romanos in memoriam M. FernándezGaliano Madrid, 113 ss.

JOHNSTON, D.E., 1983: The Prefabrication and Removal of Mosaics in Roman Britain, CIMA III/2. Ravenna, $525 \mathrm{ss.}$

LEVI, D., 1947: Antioch Mosaic Pavenents. Princeton.

LÓPEZ MONTEAGUDO, G. - BLÁZQUEZ, J.M. - NEIRA JIMENEZ, M.L. - SAN NICOLÁS PEDRAZ M.P., 1988: El simbolismo del matrimonio en el mosaico de Fuente Álamo y otros mosaicos hispanos inéditos, Latomus 47/4, $785 \mathrm{ss.}$

MAIER, F.G. - KARAGEORGHIS, V., 1984: Paphos. History and Archaeology. Nicosia.

MATZ, F., 1962: Die dionisyschen Sarkophage. II. Berlín.

MICHAELIDES, M., 1987: Cypriot Mosaics. Nicosia.

NICOLAU, K., 1983: Three new mosaics at Paphos. Cyprus, CIMA III. Ravenna, $219 \mathrm{ss}$.

OVADIAH, A., 1987: Mosaic Pavements in Israel. Roma.

PARRISH, D., 1984: Season Mosaics of Roman North Africa. Roma.

PICCIRILLO, M. et alii, 1986: I mosaici di Giordania. Roma.

SPIRO, M., 1978: Critical Corpus of the Mosaic Pavements on the Greek Mainland. Fourth/Sixth Centuries with Architectural Surveys. New York.

VOZA, G., 1983: Aspetti e problemi dei nuovi monumenti d'arte musiva in Sicilia, CIMA Ill. Ravenna, 198 ss

WAYWELL, S.E., 1979: Roman Mosaics in Greece, AJA 83

WILDE, J. et alii, 1982: An Archaeological Guide to the Ancient Kourion Area and the Akrothiri Peninsula. Nicosia.

WILSON, R.J.A., 1965: Mosaics, Mosaicist and Patrons, JRS

- 1982: Roman mosaics in Sicily: The African Connection, AJA 86,413 ss.

YACOUB, M., 1969: Musée du Bardo. Tunis. 